IZA DP No. 9890

Regulation and Firm Value: Curious Case of Transparency and Disclosure Laws in Russia

Suman Banerjee

Ronald Masulis

Sarmistha Pal

April 2016 


\title{
Regulation and Firm Value: Curious Case of Transparency and Disclosure Laws in Russia
}

\author{
Suman Banerjee \\ University of Wyoming \\ Ronald Masulis \\ University of New South Wales \\ Sarmistha Pal \\ University of Surrey \\ and IZA \\ Discussion Paper No. 9890 \\ April 2016 \\ IZA \\ P.O. Box 7240 \\ 53072 Bonn \\ Germany \\ Phone: +49-228-3894-0 \\ Fax: +49-228-3894-180 \\ E-mail: iza@iza.org
}

\begin{abstract}
Any opinions expressed here are those of the author(s) and not those of IZA. Research published in this series may include views on policy, but the institute itself takes no institutional policy positions. The IZA research network is committed to the IZA Guiding Principles of Research Integrity.

The Institute for the Study of Labor (IZA) in Bonn is a local and virtual international research center and a place of communication between science, politics and business. IZA is an independent nonprofit organization supported by Deutsche Post Foundation. The center is associated with the University of Bonn and offers a stimulating research environment through its international network, workshops and conferences, data service, project support, research visits and doctoral program. IZA engages in (i) original and internationally competitive research in all fields of labor economics, (ii) development of policy concepts, and (iii) dissemination of research results and concepts to the interested public.
\end{abstract}

IZA Discussion Papers often represent preliminary work and are circulated to encourage discussion. Citation of such a paper should account for its provisional character. A revised version may be available directly from the author. 


\title{
ABSTRACT
}

\section{Regulation and Firm Value: Curious Case of Transparency and Disclosure Laws in Russia*}

\begin{abstract}
We provide novel evidence on the effectiveness of mandated changes in Russian transparency and disclosure (henceforth T\&D) rules in boosting shareholder welfare. We focus on the staggered implementation of these T\&D reforms initiated in 2002 and implemented during 2003-07. Using difference in difference method, we find that the reforms improved earnings quality, which on average reduced the operating performance (i.e., EBIT/Assets) of treated domestically-listed (relative to our control group of cross-listed) Russian firms, but had no significant impact on their market valuation. We argue that low tax alignment, where financial statements are not used for tax purposes, made it possible for managers of domestically-listed firms to inflate pre-reforms earnings, which became difficult post-reforms, leading to a drop in operating earnings. Yet, firm values, on average, remained unchanged because the drop in earnings was roughly offset by a decrease in the required market return due to more reliable accounting information post reform. Also, T\&D reforms had negligible effects on cross-listed firms that act as our control group. Further, for domestically listed firms without a domestic controlling shareholder, post-reform reported earnings did not drop, while firm value increased significantly. For the domestically listed firms with a controlling shareholder, just the opposite occurred. Thus, a key finding of our study is that a strong governance structure is a prerequisite for significant gains in shareholder wealth following improved reliability of firm accounting information.
\end{abstract}

\section{JEL Classification: $\quad \mathrm{G} 3, \mathrm{~K} 2, \mathrm{P} 2$}

Keywords: transparency and disclosure rules, quasi-experimental analysis, domestic vs. cross-listed firms, firm performance, Tobin's Q, EBIT-to-Asset ratio, difference-in-difference method, Russia

Corresponding author:

Ronald Masulis

Australian School of Business

University of New South Wales

Sydney NSW 2052

Australia

E-mail: ron.masulis@unsw.edu.au

\footnotetext{
* We would like to thank S\&P's Governance Services team and Mihails Kuznecovs in particular for sharing the Russian data with us. Suman Banerjee would like to gratefully acknowledge funding from the SUG Tier 1 Grant of MOE, Singapore. Also, we would like to thank Olga Kuzmina, Vikrant Vig, Raghu Rao and other seminar participants at Brunel University, NTU's Brown Bag seminar, Asian Bureau of Finance and Economic Research Annual Meeting at Singapore, European Financial Management Annual Meeting at Rome, IFABS meeting at Said Business Oxford for comments and suggestions on an earlier draft. Our special thanks go to our discussants Professor T.J. Wong and Markus Senn for their valuable feedback on an earlier draft. The usual disclaimer applies.
} 


\section{Introduction}

The trust an organization builds with its stakeholders is critical for its health and wealth. Yet, trust in business is in dramatic decline all over the world, perhaps a result of companies' failure to deliver on transparency. Transparency is a key driver of corporate trust/reputation, nonetheless it is also an area in which companies commonly underperform. Thus, there is increasing external and internal pressure on organizations to become more transparent, not only from customers and employees, but also from other stakeholders such as investors and regulators. However, many researchers believe that increased transparency will not deliver greater understanding to stakeholders but will instead create a potentially significant governance burden and could result in divulgence of commercially sensitive information.

In this paper we utilize a natural experiment - exogenous changes in the transparency and disclosure (henceforth, T\&D) law in Russia around the year 2002/2003 -- to study the impact of exogenously mandated changes in corporate governance standard on Russian firm performance. ${ }^{1}$ We looked at two well-established measures of firm performance: total earnings before interest and taxes divided by total assets (EBIT/Asset), and total market value of the firm plus the book value of debt divided by total book value of assets (Tobin's Q). Our empirical findings are striking, and at least to us, quite surprising: although we find a significant drop in operating performance of only domestically listed (relative to cross-listed) Russian firms after they start disclosing higher quality accounting information to the market, such high quality disclosures does not significantly boost their firm value or Tobin's Q, on average.

This evidence suggests that before the enactment of this new T\&D law, measures of operating performance, which can be influenced by managerial discretion, are to a large extent "manufactured numbers" for domestically-listed firms. Given a very inefficient Russian tax enforcement mechanism during the 1998-2002 period, managers did not have to disclose pertinent information about new deals signed and/or the sources of the additional revenues and/or the sources of the new cost-cutting, and thus, these managers were able to inflate reported earnings quite easily. ${ }^{2}$ Given that most cross-listed Russian firms during this period

\footnotetext{
${ }^{1}$ We assume, in line with the existing literature, that the level of corporate transparency and disclosure directly affects the outside investors' perception about governance standard of the firm. See, for example, papers by Becht et al (2003), La Porta et al (1997), Fields et al (2001), Ali et al (2007) and Bae et al (2008).

${ }^{2}$ Russian Tax Code is adopted and implemented in multiple stages: The first stage, enacted on July 31, 1998, defines and regulates relationships among various agents involved in the tax system. The second stage, enacted on August 5, 2000, defines specific taxes, rates, payment schedules, and detailed procedures for tax calculations. It is amended in 2001-2003 with additions like the new corporate profits tax section and the new simplified tax system for small business. Around the same time, Russia has modified its tax accounting from being "high alignment" to "low alignment", which means that financial accounting is no longer used to calculate taxable income, and it signals a fundamental shift
} 
were listed in London, Frankfurt and New York, it is expected that these firms were subject to much more stringent disclosure rules and thus, had to provide high quality accounting information prior to the Russian T\&D reforms and as a result their performance remained unchanged after the reforms. Once more stringent disclosure laws came into force, managers of domestically-listed firms, found it increasingly difficult to inflate earnings and as a result, their reported earnings dropped significantly in the post T\&D reform era. But we do not find any perceptible effect on Tobin's $Q$ in the full sample. The obvious question is how market valuation may remain unchanged even when EBIT fell, at least for a large subsample of firms.

Suppose we view firm value as a multiple, $\mathrm{m}$ of total earnings (EBIT), where $\mathrm{m}$ is the valuation multiplier defined by the ratio of price per share to earnings per share. The overall effect of T\&D on firm valuation would depend on how $T \& D$ affected both the valuation multiple and reported earnings. An increase in T\&D means that investors give greater credence to reported performance numbers, which in turn lowers their required discount rate. Also, better corporate governance practices in the post $T \& D$ years are expected to lead to more efficient utilization of resources, which may in turn also lower the cost of capital and improve project quality. Consequently, we expect that the valuation multiples of domestic firms should rise after the TD reforms. However, the effect of increased T\&D on reported earnings would depend on reported earnings before the reform.

If prior to the required corporate $\mathrm{T} \& \mathrm{D}$ reforms, management was underreporting corporate earnings, (while reaping excessive private benefits), then afterwards reported earnings should rise. If, on the other hand, prior to mandated corporate $T \& D$ reforms, management was over-reporting earnings (compensation \& lacks tax enforcement), then earnings should drop. However, if prior to mandated corporate T\&D reforms, management was neither over-reporting, nor under-reporting, corporate earnings, then earnings should remain unchanged. Thus, we argue that rational investors recognized this inflation and accordingly discounted these firms' stated earnings to reflect the expected inflation to earnings. Therefore, the simultaneous effects of these reform on valuation multiples and reported earnings of domestic-listed firms offset each other, giving rise to an insignificant effect of the reform on the market values of this sample firms.

Further we examine if the T\&D reform necessarily resolves all the governance problems. In particular, we consider the possibility if the presence of controlling owners may

in reporting incentives. See, for example, Schneider and Enste (2002) have argued that the size of Russia's shadow economy is about $44 \%$ of its GDP in 1998-99, which primarily includes legal activities like tax evasion. 
give rise to serious governance problems (Morck et al. 2005). One could identify at least three possible mechanisms in this respect: (i) controlling owners may have much more control than cash flow rights (they typically have little real capital invested in the firm), which creates agency and entrenchment problem simultaneously. (ii) Controlling shareholders can divert corporate resources for private benefits using transactions within the pyramidal group. The result is a poor utilization of resources. (iii) Political influence, e.g., 'President's allies' (endemic in today's Russia) is plausibly related to what one controls, rather than what one owns.

Accordingly, we next distinguish between firms with/without controlling owners. While state is the controlling owner in all state firms, some of the private firms too had controlling owners with links to President Putin. In the subsample of Russian domestic firms without controlling owners we find no such decrease in reported earnings, but a significant increase in valuation. After the implementation of T\&D laws, reported earnings fell in the subsample of Russian domestic firms with controlling owners and no change in valuation was observed. We believe this earning drop roughly offsets the increased valuation multiple for these owner-controlled firms, resulting in no valuation change on average. These results suggest that T\&D reform does not affect the decision making in state firms or in closely held private domestic firms.

T\&D should increase investors' willingness to invest in projects that have relatively longer duration and projects that are relatively riskier. ${ }^{3}$ Typically, these types of investments help firms to secure long-term steady growth in cash flow. Also, high quality disclosure has a self-disciplining effect on managers - they become extra vigilant and in this process lower the likelihood of an inadvertent waste of resources. Disclosure also enables analysts to assess the firm value more accurately reflected by its stock prices and facilitates directors to make more informed decisions for maximizing shareholders' wealth and firm value. The bonding hypothesis (Siegel, 2005) suggests that managers will adhere to stricter regulatory regimes when their firm is cross-listed, because they will face the regulation and corporate governance codes of their home country as well as the foreign market.

Nevertheless, high quality T\&D has its dark sides too. For example, too much disclosure of pertinent information to the outside investors can help rivals to respond more effectively to the firm's actions (Hermalin \& Weisbach, 2011). This can then result in a loss of market share, reduced economic profit and consequently, a decline in firm value. As a result firms may adopt

\footnotetext{
${ }^{3}$ See, for example Johnson et al (2000) for a discussion on Asian Financial Crisis and the role of information.
} 
lower than optimal T\&D to prohibit too much disclosure. There are other possible frictions as well. First, firms may adopt lower-than-optimal T\&D because they are concerned that if they disclose too much information relative to their rivals then a lower firm value can result, which is an example of a variant on the prisoners' dilemma problem. Here, an exogenously mandated T\&D law can improve welfare by making all firms disclose similar levels of information and thereby removing the "perceived disadvantage" associated with unilateral adoption of a high T\&D strategy. A lack of transparency can sometimes arise due to agency conflicts. In such cases, exogenously imposed regulatory changes requiring greater $T \& D$ may prompt adverse reactions from these agents-in-control, which could lead to a fall in firm value. The danger of increasing public information can arise if agents are likely to overreact, especially if these agents have their own private information. In such cases, the effect of noise can be magnified (Morris \& Shin, 2002). Too much disclosure may likewise affect managerial incentives concerning project selection and risk taking (Goldstein \& Sapra, 2013). Thus the benefits of such regulations may be outweighed by the costs generated by such adverse reactions. ${ }^{4}$

Taken together, the net effect of disclosure on firm performance remains ambiguous. This motivates our investigation of whether exogenously mandated improvement in T\&D would necessarily enhance firm performance. The Russian T\&D law change in 2002 represents an informative quasi-natural experiment that we exploit to identify the causal effects of more transparency and disclosure. The companies studied here are included by Standard and Poor's T\&D data for the period 2003-2007. The sample companies listed as of 2003 account for more than $80 \%$ of the cumulative market capitalization of the Russian stock market as of 2007 and are all subject to the newly introduced T\&D law.

Our identification strategy exploits the staggered adoption of T\&D rules between 2003 and 2007, using the survey of seventy top listed Russian firms (see section 2 for further details) by Standard and Poor (S\&P afterwards). We hand-collect this disclosure information from the S\&P's annual yearbooks. Given that the timing of a firm's adoption of T\&D rules over the 2003-07 event window can be non-random, we employ an instrumental variable (IV) that predicts a company's adoption of the disclosure rules. In this respect, we exploit the variation in the adoption of the T\&D rules among firms with varying growth opportunities, liability ratios

\footnotetext{
4 Usually outside investors who supply funds to a firm have very little say in day-to-day decision-making / investment activities of the firm. When these decisions are taken by hired agents, they potentially may have quite different objective functions than the financiers. See, for example, Hermalin and Weisbach (2012) and Banerjee and Masulis (2014) for detailed discussion.
} 
and a local law and order index to develop a predictive model of rule adoption based on Berglof and Pajuste (2005).

Finally, we identify the effect of (T\&D) adoption scores (using the instrument generated at the first stage) by firms on their operating performance and stock valuation performance measures, after controlling for firm and sector characteristics, which can also influence firm performance. In this respect, we consider the domestic-listed Russian firms as the treatment group, while cross-listed Russian firms are the control group..$^{5}$ The underlying assumption is that cross-listed Russian firms are subject to more stringent international regulations (Siegel, 2005) compared to their purely domestic counterparts and thus, cross-listed firms will be relatively unaffected by the introduction of T\&D rules in 2003. Using firm-level panel data for the period 2000-07, ${ }^{6}$ we then use difference-in-difference (henceforth, DID) models to compare the selected performance measures of treatment and control firms before and after this reform. 7

One possible concern with the choice of these treatment/control groups is that the decision to list on a domestic/foreign exchange is generally not a random decision. In fact, it can depend on the expected costs and benefits of joining a tightly regulated foreign stock exchange (e.g., Karolyi (2006). To allay concerns about this potential endogeneity bias, we only consider those Russian firms, which were already listed on any domestic and/or international stock exchange before 2003, i.e., a year before the effects of corporate governance reforms are reflected on firm balance sheets. Thus, the timing of being listed precedes the timing of the introduction of the reforms in our analysis, which arguably would help us to minimize any potential bias in our estimates.

Later we test the robustness of our estimates in a number of ways; specifically by (i) dropping the firms that cross-listed in the post-2003 years; (ii) dropping larger firms; (iii) accounting for the presence of controlling foreign owners in domestically listed Russian firms. In order to limit any biases arising from unobserved industry-level factors, we not only employ industry fixed effects, but also industry*year fixed effects to control for unobserved industrylevel time trends. Note that the error terms are likely to be correlated at the firm level, since

\footnotetext{
5 Since 1996 a growing number of Russian firms got listed in various international stock exchanges -- particularly in the NYSE and the London Stock Exchange (LSE) in a bid to seek credibility and deeper liquidity, which Moscow exchanges could not provide. These firms are partly regulated by the US Rule 144A and rules governing GDR, which are more stringent than the Russian CG laws.

${ }^{6}$ We exclude the year 2008-09 as the Russian economy was hard-hit by the 2008 financial crisis -- an exogenous shock that could have contaminated our effort to capture the impacts T\&D reform on Russian firm performance. 7 We also tested for the parallel trends between the domestic and cross-listed firms ensuring that these two groups of firms only differed in the treatment.
} 
firms that abide by the CG law in period 1, are also likely to do so in period 2 and so on. Therefore, clustered standard errors at the firm level (e.g., Bertrand et al., 2004) are used to reduce any estimation bias arising from this serial correlation.

Our analysis contributes to a sizable and growing literature on corporate governance. Schleifer \& Vishny (1997) highlight the beneficial influence of strong corporate governance laws on firm performance and value. ${ }^{8}$ While the earlier literature tends to focus on the separation of ownership and board composition in line with an agency theory perspective (e.g., Jensen \& Meckling (1976), the focus in the 1990s shifted to the effects of differences in the legal rules that define creditor and shareholder rights (e.g., La Porta et al. (1998) and others). More recently, attention has turned to assessing the importance of various government regulations including T\&D laws. Patel et al (2002) is one of the first US studies to show that firms with good T\&D have a lower equity cost of capital. Gompers et al (2003) included T\&D as one component of their corporate governance indices and reported that stronger shareholder rights in the U.S. led to better firm performance.

Turning to the limited work on Russian corporate governance, there are three recent studies, namely, Black et al (2001), Black et al (2006) and Goetzmann et al (2003). While Black et al (2001) use a single cross-section of 21 Russian firms in 1999, Black et al (2006) use pooled OLS with fixed and random effects estimates for sample firms over 1999-2004 to estimate a macro effect of their corporate governance index on firm value, which however, suffers from an endogeneity bias. While the beneficial effects of CG reforms appear pronounced using OLS estimates, the estimated effects are greatly reduced in the fixed effects estimates Black et al (2006) use. However, their study tends to highlight the beneficial effect of the reforms on firm values and does not address any concern arising from the endogeneity of corporate governance index.

We extend the existing literature in a number of ways. Most importantly, we argue that there can be circularity between implementation of the CG reforms and firm performance. Hence, we use a quasi-natural experiment to break this circularity to establish the causal effect of the reforms on selected firm performance measures. In this respect, we exploit the variation in the performance measures between domestically listed treated firms and cross-listed control

\footnotetext{
8 There is evidence from around the world that firms with better corporate governance practices enjoy lower cost of capital La Porta et al (2000); Ashbaugh et al (2006); Errunza et al (2001); lower credit rate spreads (Yu, 2005) and Brown (2006).
} 
firms to identify the differential effects of the reforms on both types of firms, using a differencein-difference approach.

We find that the reforms were successful in improving accounting accuracy, but were not fully successful in strengthening governance for these sample firms. Since the domestic Russian firms inflated earnings in the pre-reform years, 2002 adoption of the T\&D rules resulted in a significant drop in reported earnings by domestically listed firms, especially among state-controlled firms. In contrast, the reforms boosted earnings quality. These results highlight the limits of these reforms.

\section{Data}

Our main information sources are the Bureau Van Dijk's OSIRIS database with firm-level data on Russian energy and non-energy companies and for company transparency and disclosure information, the S\&P annual yearbooks of Russian companies, which are widely used data resources for academic research on Russian firms. ${ }^{9}$ We use the S\&P's T\&D data available for the period 2003-07. T\&D data covers various indices on ownership structure, shareholder rights, financial and operating performance, and board and management structure and processes. We merge the T\&D data compiled by S\&P with firm-level accounting data extracted from the OSIRIS database available from Bureau van Dijk. Then we construct a composite T\&D scores -- obtained by using factor analysis of these available indices, which allows us to test our central hypothesis that better T\&D improves a firm's performance in Russia. We provide a detailed description of the construction of our two transparency and disclosure measures, specifically a T\&D score and a T\&D reform indicator in Appendix 1.

To obtain information on the dates that Russian firms initially listed internationally, we rely on the Initial Public Offering (IPO) data from Price Waterhouse Coopers (2008). Our analysis of the T\&D reform data covers the period 2003-2007, while our binary corporate governance reform indicator covers selected Russian firms between 2000 and 2007, which is a period of rapid economic recovery (preceding the financial crisis of 2008) under President Vladimir Putin.

\footnotetext{
${ }^{9}$ See, e.g., Black (2001); Klapper and Love (2002); Goetzmann, Spiegel and Ukhov (2004); Black, et al (2006); and Black, Love and Rachinsky (2006).
} 


\subsection{Transparency Indices}

Our primary data source for the characteristics of Russian companies is the S\&P's annual T\&D indices, consistently constructed for the 80 largest Russian companies with the most liquid stocks over the period 2003-2007 (It represents $80 \%$ of cumulative market capitalization of Russian stock market in 2007). These indices pertain to the adoption, rather than the introduction of the reform. Using (2003-2007) S\&P annual reports, we analyze the following T\&D indices:

- T\&D financial and operational information

- T\&D ownership structure and shareholders rights

- T\&D board and management structure

We then used the principal component analysis to generate a composite T\&D score. The Russian firms adopted these reforms over the 2003-07 period. By 2007, our entire sample of firms adopted the reforms, although the extent of adoption varied somewhat across the firms.

S\&P applies two criteria in selecting companies for inclusion in its database: size and liquidity. As a rule, the stock's liquidity is a positive function of company size, except in cases of minor free-float, i.e., when only a small fraction of a firm's shares are publicly traded. Each T\&D index is based on about 30 survey questions for each of its components: T\&D financial and operational information, T\&D ownership structure and shareholders rights, T\&D board and management structure. These questionnaires (see Appendix 1) are circulated to the top Russian firms in various industries like telecommunications, energy, manufacturing, and advertising. The S\&P database is based on information taken from three major public information sources: annual reports, web-based company disclosures, and public regulatory reports. S\&P views corporate transparency as an important factor affecting a firm's attractiveness to investors and an important element of corporate governance. The study includes approximately 70 of the largest listed companies with the most liquid assets. Companies included in the survey account for about $80 \%$ of the cumulative capitalization of the Russian stock market and these companies represent a major portion of the Russian economy in terms of assets and operations.

Figure 1 shows the trends in the T\&D indices over the sample period. Clearly, the energy sector's average composite T\&D index rose from $40 \%$ in the first two years after the introduction of the CG reform to around 55\% in 2007. Although non-energy companies have a higher average T\&D level than energy companies in 2003, by 2007 energy companies are very similar to non-energy companies, highlighting that the composite index of transparency 
rose faster in the energy sector over this 4-year period. Although Russia adopted a "comply or explain" (COE) approach, it appears that the law's adoption is incentive compatible, as an ever increasing proportion of these sample firms adopted $T \& D$ rules to facilitate their external capital raising. By 2007 all of the sample firms had adopted these rules, so concerns about implementation of this law should be quite limited. ${ }^{10}$

We use the composite disclosure index to create an indicator variable TD-Dummy to show a firm's the adoption/implementation of the reforms. ${ }^{11}$ The indicator takes a value 1 if the composite T\&D score was positive during 2003-07 and 0 otherwise. We also construct an indicator variable to capture the law's introduction (rather than the adoption of the reforms) which we title Reforms 2003. It takes a value 1 for the 2003-07 period and 0 otherwise. An alternative reform variable that we use in robustness is called Reforms 2004. It takes a value 1 for 2004-07 and 0 otherwise. This indicator assumes that the effect of the reforms is first realized in a firm's 2004 financial statement.

\subsection{Firm Performance Measures}

We use two alternative indices of firm performance - one market based and one accountingbased. Tobin's Q is a widely used market-based measure of firm performance. For detailed explanation for its use, see Mueller and Reardon (1993), Denis and McConnell (2003) and La Porta et al. (2002). Tobin's Q is defined as a firm's equity capitalization plus book value of debt divided by book value of total assets. We also use earnings before interest and taxes (EBIT) divided by book value of total assets, which we label ROA, as a measure of firm's operating performance. The underlying idea is that EBIT is amenable to earnings manipulation, while the numerator of the Tobin's Q measure is market determined. As such a comparison of the estimates of Tobin's Q and ROA before/after the reform can help detect accounting manipulation.

Figure 2 shows the trends in annual average ROA and Tobin's Q for our full sample. Note that we have multiplied the EBIT to total assets ratio by 10 to make these figures

\footnotetext{
${ }^{10}$ For the period as a whole, the average values of T\&D indices as well as performance measures tend to be higher among the non-energy sector firms. However, we need to bear in mind that the observed T\&D scores are not random as the Russian firms have some discretion in their adoption of the T\&D rules, especially given the softlaw approach to implementation of Russian CG codes within 2003-07; however, all sample firms adopted the reform by 2007; we accordingly adopt our methodology to reflect this staggered implementation of the reform (see further discussion in the methodology section). This is further discussed in section below.

${ }^{11}$ Note that there is a high degree of correlation among different components of the T\&D reform: firms who have high scores in T\&D in financial and operational procedures, also score highly in T\&D ownership and T\&D Board Management. As such we are unable to include these three scores simultaneously in our analysis.
} 
comparable with the Tobin's Q figures. Clearly there is a dip in ROA around 2002-2003 as the T\&D reform legislation is enacted, then ROA improves marginally during 2004-2006, but drops thereafter. In contrast, Tobin's Q steadily improves from 2002 onwards. Over the full sample period, Tobin's Q increases from an average of 0.79 in 2000 to an average of 2.21 in 2007. The question is whether these patterns remain, after we control for all the other factors that could also affect firm performance. In order to address this question, we move to a multivariate regression analysis described in sections 3 and 4.

\section{Insert Table 1}

Table 1 summarizes the descriptive statistics for the two firm performance measures and the other control variables in our sample. Note that the average value of Tobin's Q is generally greater than one for our sample, suggesting that the market value of a company is generally greater than the book value of its recorded assets. The average values of various $T \& D$ indices are approximately $50 \%$ for all industries taken together; the latter suggests that even when a firm adopts the rules, they only adopt approximately half of the T\&D provisions covered in the questionnaire (see the Appendix). In comparison, the average T\&D scores are slightly higher for the non-energy sector firms relative to energy firms.

Turning to other firm characteristics, we see that the average total liabilities to total assets ratio is about 0.45 . We measure market concentration using a Herfindahl index of publicly listed firms. ${ }^{12}$ Table 2 shows that the average Herfindahl-index is high for all the industry sectors considered in our analysis, implying a weak competitive market environment in Russia for most industrial sectors. We also control for how long a firm is publicly listed. Table 2 shows that the average age of the sample firms in our study is 19 years. Examining company age by sectors, we see that firms in the oil-and-gas production sector have an average age of 6 years, while companies in the utilities sector are much older with an average age of 30 years.

\subsection{Identification and the Quasi-Natural Experimental Set-up}

In this section, we explain how we can exploit the exogenous shock associated with the introduction/adoption of the 2003 Russian T\&D rules as a quasi-natural experiment with a view to identifying the causal impact of the reform on selected indices of firm performance. To this end, we use the binary variable TD-Dummy to account for the adoption of the reforms by sample firms during this five year period.

\footnotetext{
${ }^{12}$ As a rule of thumb, a Herfindahl index below 0.10 signals low market concentration, while a Herfindahl index above 0.18 signals high concentration. An index value falling between 0.10 and 0.18 indicates that the industry is moderately concentrated.
} 
Our analysis begins just after Vladimir Putin came to power in 2000 and led Russia through a period of rapid economic recovery following the 1998 Rubble crisis. During this period a growing number of large Russian firms cross-listed on foreign stock exchanges. Internationally most cross-listed Russian firms chose to list on either the London Stock Exchange (LSE) or one of the major US stock exchanges. Firms from emerging markets such as Russia that traded on the LSE used of Global Depository Receipts (GDRs) introduced in 2001. In addition, foreign firms listing in the US must have followed Rule 144A. ${ }^{13}$ Further, Sarbanes-Oxley Act or SOX was enacted in the US in 2002, which required new or enhanced standards for all U.S. public company boards, management and public accounting firms. As a result of SOX, the CEO and CFO are required to personally certify the accuracy of the firm's financial reports. Penalties for fraudulent financial activity are also substantially toughened. In addition, SOX increased the independence of outside auditors who review the accuracy of corporate financial statements, and increased the oversight role of boards of directors. In comparison, the listing requirements in domestic Russian exchanges were lax.

In analyzing the impact of the T\&D reforms for Russian firms, we view the purely domestically listed Russian firms as the treatment group, and the cross-listed Russian firms as the control group, as they are unlikely to be affected by the 2003 T\&D rules. Subsequently a comparison of selected firm performance measures for treatment and control groups before/after the introduction of the reforms, enables us to identify the causal (differential) effect of the reforms among the treated domestically listed Russian firms in our sample.

We use the Initial Public Offering (IPO) data available from the Price Waterhouse Coopers (2008) to identify the first year of listing on an international stock exchange. As indicated above, focusing on sample of firms covered by S\&P over 2003-07 means that all the firms in our sample must be listed by 2003 , before the impacts of the T\&D reforms are realized. It is also noteworthy that only about $19 \%$ of the 80 Russian firms in our sample are internationally listed by 2003 .

An important identification assumption for the successful implementation of the difference-in-difference method necessitates that the treatment and control groups of firms differ only due to the treatment (which is the introduction/adoption of the reforms in our case). In other words, the following conditions must hold: (i) impact of time is constant across treatment and control groups (domestic/ foreign) and (ii) impact of group is constant across

\footnotetext{
${ }^{13}$ Rule 144A permitted firms to raise capital from "qualified institutional buyers" (QIBs) without requiring registration of the securities and elaborate compliance with U.S. GAAP. This rule was implemented in 1990.
} 
time. This is often termed the parallel (or common) trend condition, which we test later in our analysis (see Table 5 and further discussion in section 4).

\subsection{Descriptive statistics}

Table 2 compares the means for selected characteristics of foreign and domestic listed firms in our sample. In general, domestic-listed Russian firms tend to be older and slightly larger and also have a slightly higher debt to assets ratio; also note that these mean differences are statistically significant in our sample. The same cannot be said for all the outcome variables in our sample. While the mean values of the Tobin's Q and the ROA ratios in the pre-2003 period are somewhat different for domestic versus cross-listed Russian firms, the difference is never statistically significant for any of these indices in the pre-reform years. When we compare the means of these two performance measures among domestic and cross-listed firms in the postreform years 2003-07, we obtain quite different outcomes. While the average performance goes up for the domestically listed Russian firms in the post-reform years using either performance measure, the difference is only statistically significant for Tobin's Q ratios in our sample.

Insert Table 2

There is one possible concern with these findings, which is linked to the fact that both performance measures involve "assets," which are subject to manipulation. So before we proceed with our analysis, it is important to evaluate whether a firm's total assets remain relatively unchanged following the reforms (i.e. no adjustment in the typical firm's disclosure of total assets). A simple mean comparisons using a conventional t-test shows that the average total assets or growth in total assets (defined as annual rate of change of total assets) does not change significantly after the introduction of the T\&D reforms (see table A4) regardless of the reforms measure used. We next regress the TD-indicator as well as Reforms on the log of total assets, after controlling for firm, year or alternatively "firm times year" fixed effects. It follows from Appendix Table A5 that both measures for T\&D reforms remain insignificant (although the estimated coefficient is positive) in each case. So there is no evidence to suggest that the typical firm's total assets changed significantly in the post reforms period for our sample. Accordingly, we proceed to compare changes in EBIT and market capital among domestic and cross-listed firms before/after the reforms. 


\section{Methodology}

Our primary objective is to identify the causal effect of the introduction of T\&D rules on firm performance in Russia by exploiting the inter-firm variation in the adoption of T\&D rules in our sample. In this respect, we utilize the natural experiment framework (see discussion in section 2) and estimated a difference-in-difference model of performance, exploiting the variation in firm performance between domestic (treatment group) and cross-listed (control group) Russian companies before and after introduction of the T\&D rules (see section 3.1).

\subsection{Difference-in-difference estimates of firm performance}

Given that a growing number of Russian firms, especially the larger ones, started gaining international listing status beginning in 2000 and they are differentially affected by domestic and international corporate governance codes, we treat the internationally listed Russian firms as our control group. Use of S\&P's sample ensures that all sample firms are listed on some Russian stock exchange by 2003 . We then code any of these sample firms as internationally listed only if they are listed on a major foreign stock exchange by 2003 (before the introduction of the reform). This is because the likelihood of being listed internationally is unlikely to be random; it is a matter of choice made by these firms (which increases its value). As such, we ensure that the timing of listing (domestic/foreign) precedes 2003, the year when the CG reforms went into effect, which is disclosed in firm annual financial reports. We argue that this restriction helps us to allay concerns about the potential simultaneity bias, if any, arising from simultaneity between the likelihood of being listed and the effect of the reform. ${ }^{14}$ Accordingly, we create a binary variable 'Domestic' that takes a value 1 if by 2003 a sample firm is only listed domestically on a Russian stock exchange and 0 if listed internationally. This allows us to exploit the variation in the adoption of CG codes (captured by TD-Dummy) between domestic and cross-listed (captured by Domestic) Russian firms to identify the differential (and causal) effect of the CG reform on firm performance. To avoid endogeneity concerns about the timing of a company's adoption of the T\&D reforms, our analysis focuses on a comparison of years 2003 and 2007, when the full sample of domestic firms had adopted the T\&D reforms. We exclude firms that list internationally between 2003 and 2007.

We begin our analysis using the two-period firm-level data to compare two widely accepted firm performance measures, Tobin's Q and EBIT /Assets (at the mean level) in the pre and

\footnotetext{
${ }^{14}$ Later on we also test the robustness of our estimates by dropping the Russian firms which became internationally listed in the post-2003 period.
} 
post-reforms period across domestic and internationally listed Russian firms. Our objective is estimate the differential effect of $\mathrm{CG}$ reforms on treated domestic firms.

\begin{tabular}{|l|l|l|l|}
\hline Tobin's Q & Pre & Post & Difference \\
\hline Domestic (treatment) & 0.73 & 1.70 & -0.97 \\
\hline Foreign (control) & 0.93 & 2.87 & $\mathbf{- 1 . 9 4}$ \\
\hline Difference & $\mathbf{- 0 . 2 0}$ & -1.17 & $\mathbf{0 . 9 7}$ \\
\hline
\end{tabular}

First, considering Tobin's Q, we observe the following: (i) Counterfactual 1: Pre-intervention difference between treatment and control is -0.20 . (ii) Counterfactual 2: control group time difference is -1.94 , which estimates the difference for the treatment group in the absence of the intervention. (iii) The estimated intervention effect is 0.97 for the treatment group.

\begin{tabular}{|l|l|l|l|}
\hline EBIT/Assets & Pre & Post & Difference \\
\hline Domestic (Treatment) & 0.13 & 0.135 & 0.005 \\
\hline Foreign (Control) & 0.07 & 0.127 & $\mathbf{- 0 . 0 5 7}$ \\
\hline Difference & $\mathbf{0 . 0 6}$ & 0.008 & $\mathbf{- 0 . 0 5 2}$ \\
\hline
\end{tabular}

Next we turn to the earnings based performance measure and find that the impact of the reform is quite different for earnings; (i) pre-intervention difference between treatment and control firms is 0.06; (ii) the change in operating performance for the control firms after the reforms is -0.057 , which estimates the performance of the treatment firms without the intervention. (iii) Thus, the estimated intervention effect for the treatment group is -0.052 .

Since these are bivariate mean comparisons, we need to reassess these finding in a regression framework to better identify the differential impact of the reform on operating performance and Tobin's Q of domestic listed firms relative to foreign listed Russian firms, after we control for all other factors that can influence these firm performance measures. To this end, we use a difference in difference (DID) model using firm-level panel data for 200007 period. The DID method we use is in its simplest form, largely a two-period panel data model with fixed effect. It assumes the treatment status (relative to control group) before and after the introduction of the reform. Since we have yearly data for 2000-2007, we consider a variant of the DID model using annual panel data for the full sample. Accordingly, we specify a DID model for the selected indicators of firm performance, Tobin's Q or EBIT/Assets of the $\mathrm{i}$-th firm in year $\mathrm{t}$ as follows: 
$\mathrm{Q}_{\mathrm{it}}=\beta_{\mathrm{TD}} \times \mathrm{TD}_{- \text {Dummy }_{\mathrm{i}}}+\beta_{\mathrm{D}} \times$ Domestic $_{\mathrm{it}}+\beta_{\mathrm{TDD}} \times\left(\right.$ TD-Dummy $\mathrm{i}_{\mathrm{i}} \times$ Domestic $\left._{\mathrm{i}}\right)+\beta_{\mathrm{X}} \mathrm{X}_{\mathrm{it}-1}+$ Sector $i+\tau_{t}+\left(D i * \tau_{t}\right)+u_{i t} \ldots \ldots . .$. Eq. $(2), t=2000, \ldots . .20007$.

The variable of interest is the estimated coefficient of the interaction term $\beta_{\mathrm{TDD}}$, which determines the differential effect of the implementation of the $T \& D$ reforms on the performance measures of domestic-listed firms in our sample, controlling for all other factors.

Consistent estimate of $\beta \mathrm{TDD}$ from equation (2) necessitates that our central arguments, namely TD-Dummy and Domestic dummy are not correlated with the error term. An essential precondition for ensuring this is that the parallel trends in outcome variables are the same for treatment and control groups and also that there are no spillover effects (only the treatment group received the treatment and control group does not). Using repeated firm-level observations over time, we estimate a separate regression to test the parallel trend assumption using annual data in our sample. Since our sample firms adopted the T\&D reforms in the 20032007 period, we include all the time interactions from 2001 to 2007. The results summarized in Table 5 suggest that the interaction terms (Domestic*Year) are never statistically significant. Thus, we conclude that the control and treatment groups meet the parallel trends assumption.

In order to identify the causal effect of the intervention in a natural experiment framework, we need to control for a wide range of observable and unobservable factors so as to ensure that the treatment and control groups are identical in all other ways (except by the intervention). The set of variables $\mathrm{X}$ includes firm size (measured by log of total assets), firm age (measured in years), and intangibility ratio (intangible fixed assets to total fixed assets). Choice of these variables has been guided by the literature, e.g., Franks and Mayer (2002), Rajan and Zingales (1995), and Booth, et al. (2001), de Haas and Peters (2004), Cole (2008) and Driffield and Pal (2010).

Since our methodology focuses on comparing between domestic and cross-listed Russian firms, we employ group (defined by whether a firm is domestic or cross-listed) fixed effects (rather than firm fixed effects which instead focus on the within firm variation of performance over 2000-07) estimates. We also control for the industry/sector and year fixed effects to control for time invariant sector/year specific unobservable variables that could be significant in explaining firm performance. In particular, sector controls capture the effects of unobserved sector wide factors including taxes, and/or any other exogenous shocks that may affect performance. Further, we include (Industry* Year) fixed effects to control for industry-specific unobservable time trends (e.g., any shock introduced by changes in oil price) that may also 
play an important role in explaining firm performance measures during this critical phase of economic development in Russia.

One possible problem with DID model using panel data is that it ignores the autocorrelation in the errors of the within firm-year cells. We use cluster bootstrap (which maintains the autocorrelation structure by keeping all the observations for a given firm together) to redress this estimation bias (e.g., see Bertrand et al. 2004). This is an improvement over the standard procedure of cluster-robust standard errors which may not work well when number of clusters is small; thus the cluster bootstrap procedures provide an asymptotic refinement.

\subsection{Addressing endogeneity}

We estimate firm performance as a function of T\&D adoption. Given the staggered introduction of T\&D reforms over 2003-07, the timing of reform adoption before 2007 is a matter of firm choice and as such it is unlikely to be random. There are several possible avenues for endogeneity to arise here: (i) timing of the adoption could be simultaneous with firm performance: just as adoption affects performance, performance can also affect adoption. (ii) there can be some firm-level omitted variables, either observable or unobservable, e.g., ownership structure indicating voting and cash flow rights of controlling owners. If this is correlated with reform adoption, the OLS efficiency condition that $\operatorname{cov}(\mathrm{x}, \mathrm{u})=0$ is violated in the firm performance equation. In order to address these endogeneity concerns, we use an instrumental variable approach with 2SLS estimation, which is common in the literature.

We argue that the costs and benefits of disclosing more information are heterogeneous across firms. Thus, in addition to various controls for firm characteristics like firm size, age, R\&D share (labelled as intangibility) and the industry's Herfindahl index level, we use the following identifying variables to determine firm's adoption of T\&D rules following Berglof and Pajuste (2005): a firm's liability ratio, growth of sales and the law and order index for Russia over 2003-07. Clearly the law and order index of the country over 2000-07 is crucial since we expect greater reform implementation as overall law and order conditions improve.

Second, we expect firms with greater leverage to be less inclined to adopt the transparency and disclosure rules because it could reveal a firm's more serious financial difficulties to the market. A fast growing firm with greater growth of sales may be reluctant to disclose financial information, since the firm may reveal valuable information competitors about its product market performance. Without an external financing need, there is no obvious 
benefit from this disclosure, while there can be substantial costs of revealing information to competitors. ${ }^{15}$

Nevertheless, while recognizing the prior incentives, a firm's disclosure calculation is likely to change as most firms in the country adopt these rules. Accordingly, we first determine the TD-Dummy variable, i.e., the adoption of T\&D rules by a firm, even if partially, for a panel regression with either firm, year and also firm*year fixed effects. These fixed effects control for omitted firm, year and also firm-level time varying unobserved factors, thus helping us to minimize any omitted variable bias in our estimates. We use the first-stage estimates of the TD-Dummy to generate its predicted value. These predicted values are then used as an instrumental variable (TD-Dummy-IV) for determining a firm's performance measures in the second stage equation. The underlying logic behind this approach is that after controlling for all the relevant observable and unobservable factors influencing TD-Dummy, the errors in the predicted T\&D scores can be considered random in determining firm performance in the second stage. We perform several tests (including those for instrument validity, instrument relevance and over-identification) to assess the validity of our IVs in section 4.

\section{Results and discussion}

This section presents and analyses the estimates of Eq. (1) for our sample. We present our main results and also various robustness tests.

\subsection{Determinants of T\&D adoption}

Table 3 summarizes the estimates of TD-dummy which is an indicator of the staggered adoption of the T\&D reforms by our sample firms over the 2003-07 period.

\section{Insert Table 3}

After controlling for various firm-level characteristics, we focus on the estimates of the identifying variables. First, a higher value of the law and order index is associated with a greater likelihood of adoption, while a higher value of a firm's total liabilities is associated with a

\footnotetext{
${ }^{15}$ We test that the first stage identifying variables are relevant for the firm's adoption of the reforms (first stage) and are also uncorrelated with the estimated residuals of the firm performance measures (second stage). See further discussion in section 4 .
} 
lower likelihood of adoption. The signs of these estimates are consistent with our expectations. The coefficient estimate of sales growth is negative, although statistically insignificant. As such, there is no evidence that sales growth has a significant impact on the likelihood of T\&D adoption among our sample firms. ${ }^{16}$ We use these estimates to predict the value of the TDDummy labelled as TD-Dummy-IV, which we used to estimate firm performance in the second stage.

\section{Insert Table A1}

First, we need to show that firm performance does not depend on these identifying variables (the second stage dependent variables) - tests for the validity of this condition are shown in Appendix Table A1 for both EBIT share and Tobin's Q. Note that none of the instruments are individually significant in determining a firm's performance in our sample period.

Second, we test the relevance condition of the instruments, which is essential for the efficiency of the performance estimates in the second stage. A test of instrument relevance relies on the joint test of significance of the three identifying variables in this case, i.e.,

(1) laworder $=0$

(2) totalliab_totalassets $=0$

(3) growthsales $=0$

The resultant F-statistic is $\mathrm{F}(3,41)=7.48$, which allows us to reject the null hypothesis at the $1 \%$ level of significance. Although the growth of sales variable is insignificant individually, jointly all three instruments are statistically significant.

\section{Insert Table A2}

Third we test for instrument validity. It is not possible to directly test the assumption that $\operatorname{cov}(z, u)=0$ because the error term is unobservable. We can use a naïve regression to show that the instrument TD-Dummy IV is orthogonal to the estimated residuals of two firm performance regressions. For this purpose, we regress TD-Dummy IV on the estimated residuals obtained from the two firm performance regressions (see Appendix Table A1). The t-statistic associated with TD-Dummy IV is low and statistically insignificant in Table A1.

\footnotetext{
${ }^{16}$ Note however that all the instruments including growth of sales are jointly significant in determining adoption of the reform (see the instrument relevance test in Section 4).
} 
Further, the estimated F-statistics for TD-Dummy IV=0 are 0.05 and 1.151 respectively for the EBIT share and Tobin's Q regressions, thus, supporting orthogonality, and failing to reject the exclusion restriction. While it is not possible to prove that the instrument meets the exclusion requirement, we do find weak support for the instrument meeting the exclusion restriction in these two firm performance regressions.

Given that we use three instruments to determine one potentially endogenous variable, the adoption of T\&D reforms, we also need to conduct an over-identification test. Intuitively, the test of the over-identifying restrictions evaluates whether all possible subsets of the instruments that facilitate identification yield very similar estimates. In the population, these different subsets should produce identical estimates if the instruments are all truly exogenous. The relevant Hansen J statistics for EBIT share and Tobin's are shown below

Ebit_ta: Hansen J statistic (overidentification test of all instruments): $\quad 0.365$

$$
\text { Chi-sq(1) P-val }=0.54563
$$

Tobin's Q: Hansen J statistic (overidentification test of all instruments): $\quad 0.965$

$$
\text { Chi-sq(1) P-val = } 0.32602
$$

The null hypothesis for each performance variable is that $\mathrm{J}=0$, that is, the over-identification restrictions are valid. Since the p-values of the EBIT share and Tobins's Q are respectively 0.55 and 0.32 in our sample, we accept the null hypothesis.

While some researchers have reservations about the usefulness of these tests, all the above evidence taken together fails to reject the exogeneity of the instruments used here and also clearly supports the IVs relevance and validity, implying that these IVs do not directly impact the selected indices of performance.

\subsection{Pre-reform comparisons of domestic and cross-listed firms}

Table 4 compares the performance estimates of domestic firms (as captured by the dummy Domestic) in the pre-reform years 2000-02 relative to those for the cross-listed firms (our control group), after controlling for firm size, age, intangibility ratio and industry sector. Columns (3)-(4) show the estimates for pre-adoption years, which vary over our sample firms.

Insert Table 4 
Ceteris paribus, the estimated coefficient of Domestic is negative and significant in the Tobin's Q regression in column (1), but positive and significant in determining EBIT/Assets in column 2. There is thus evidence that domestic-listed Russian firms (relative to the cross-listed ones) had a significantly lower market valuation, but a higher EBIT/Assets ratio in the pre-reform years, holding other factors constant. We obtain similar results when we consider pre-adoption years for our sample firms (see column 4 estimates). In other words, these results highlight the evidence of earnings inflation among domestic-listed Russian firms in the pre-reform years, which was feasible given that firm financial statements were not used for tax purposes (Goncharov and Zimmerman, 2005). The latter was facilitated by change from a 'high' alignment to a low tax alignment regime as of 2001. This allowed senior executives to aggressively inflate firm earnings/profitability for various reasons (e.g., see Healy and Wahlen, 1999), which was highlighted in the U.S. by the Enron, WorldCom, McAfee etc. scandals.

\subsection{Difference-in-difference estimates of firm performance}

The main question that we examine here is whether the adoption of the 2003 T\&D reforms (which is first noted in 2004 firms' balance sheet data) has a significant impact on our measures of performance for our sample firms. Theoretically, we argue that the sign of the overall effect can be ambiguous since the beneficial effects of the CG reforms can be more than offset by the negative effects of $T \& D$ reforms. In this section, we use our data to explore if the effects of the reforms on firm performance are beneficial or not.

Before proceeding to discuss the DID firm performance estimates, we do a simple test of the parallel trends assumption in our sample.

\section{Insert Table 5}

Table 5 summarizes these estimates where we regress performance measures on domestic and year dummies and also the interactions of the domestic dummy with each of the year dummies. The table shows that the interaction terms (Domestic*Year ${ }_{\mathrm{t}}$ ), $\mathrm{t}=2001 \ldots ., 2007$ are statistically insignificant, suggesting that the average performance of the treated domestic firms is not significantly different from that of the control firms in years prior to the adoption of the reforms. We take this as confirmation of the parallel trends assumption for the outcome variables (Tobin's Q and EBIT/Assets) among the treatment and the control groups in our sample. 
Insert Table 6

We start with the analysis of the effects of the T\&D reforms on selected measures of earnings management. Table 6 summarizes the difference-in-difference estimates of earnings management. We consider four possible and conventional measures of earnings management: EQ1 is the ratio of EBIT to cash flow, while EQ2 is the ratio of sd of EBIT to sd of cash flow. Finally EQ3 is the ratio of sd of EBIT to mean cash flow and EQ4 is the ratio of operating accruals to total assets. Note that the interaction term Domestic*TD-dummy IV is positive and statistically significant for EQ1, EQ2 and EQ4, and is only insignificant for EQ3. Thus, the evidence from Table 6 is that the EQ1, EQ2 and EQ4 are all significantly higher among domestic firms after the reforms.

Second, we focus on the difference-in-difference estimates of firm performance as summarized in Table 7. Columns (1)-(2) show that group fixed effects non-IV estimates of performance, while columns (3)-(4) report corresponding IV estimates (using TD_DummyIV), after controlling for all the other factors.

\section{Insert Table 7}

Given the potential endogeneity of firm adoption dates of T\&D reforms, we focus our attention on columns (3) and (4) using the TD-Dummy-IV variable that is generated using the Table 3 estimates. We also test that these regressions satisfy the instrument validity test, i.e., the instrument TD-Dummy_IV is orthogonal to the estimated residuals of two firm performance regressions. We find that the estimated F-statistics are 0.05 and 1.151 respectively for EBIT share and Tobin's Q regressions, thus supporting the validity of the instrument for the firm performance regressions.

These IV estimates highlight the differential effects of the reforms on Tobin's Q and EBIT/Assets using the 2000-07 panel data. The estimated coefficient of the interaction term Domestic $\times$ TD-Dummy-IV, suggests a significant negative effect of the T\&D reforms on EBIT/Assets among domestic-listed firms (relative to cross-listed firms). However, the differential effect, although positive, remains insignificant for Tobin's Q. In other words, the reforms result in lower EBIT/Assets, a performance measure that appears to be inflated in the pre-reform years (as shown in Table 4). In contrast, the effect of the reforms on market valuation remains insignificant (although positive) among the Domestic firms.

Interpreting these results rests on whether firm total assets substantially change in the post reform years. In order to test this proposition, we first use a simple t-test to compare mean 
values of total assets, growth of total assets and log (total assets) before and after the reforms for our sample firms.

\section{Insert Table 7a}

The results, which are summarized in Table 7a, highlight the invariance of total assets before/after the reforms. In particular we find the mean values of total assets, growth of total assets and $\log$ (total assets) are not significantly different after the reforms are introduced. [year to year?]

\section{Insert Table $7 b$}

Further, in Table 7b, we regress the log of total assets on different indices of the reform's implementation (TD-Dummy IV) and introduction (Reform 2003 and Reform 2004), ${ }^{17}$ after controlling for industry and year fixed effects. Again these regressions suggest that the coefficient estimates of the various reform indices (pertaining to introduction and adoption) insignificantly affect the log of total assets. The prior finding suggests that total assets in the post reforms period are relatively stable. This is important to test since both Tobin's Q and EBIT/Assets use total assets as denominators and this invariance helps us to interpret our results accurately. As such, a fall in the EBIT share ratio can be interpreted as a fall in the EBIT share and a rise in Tobin's Q can be interpreted as an increase in firm valuation.

Given that total assets remained stable, we find that domestically listed Russian firms were inflating earnings in the pre-reform period. However in the post-reform environment of higher transparency, "inflating earning" becomes difficult and hence earnings drop. However, firm valuation remains unchanged in the post-reform years, which is only possible if the decline in reported earnings was roughly offset by a rise in the market's valuation multiplier $\mathrm{m}$ for domestic-listed firms.

\section{Insert Table 7c}

Finally, Table 7c shows the performance estimates of cross-listed Russian firms, which confirms our expectation that the reforms did not significantly affect their earnings or market valuation, as indicated by an insignificant coefficient estimate for TD-Dummy-IV, after controlling for all the other factors

\footnotetext{
${ }^{17}$ We try two possible cut-off point 2003 and 2004 for the introduction of the reform respectively with a view to see if they yield different results.
} 


\subsection{Alternative reform variables}

So, far we have used the TD-dummy (or TD-Dummy-IV) as the proxy for the adoption of the reforms by our sample firms. These measures take the value 1 when the overall T\&D score is positive for a firm and 0 otherwise. With this indicator, we are considering the actual implementation of the T\&D reform, rather than the mere passage of the T\&D law. To test whether our central results hold when we replace this adoption indicator variable by the postreforms indicator variable, Reform 2003, which takes the value of 1 if and only if the observation belongs to the reform period 2003-07, and is 0 otherwise.

Insert Table 8

The results are summarized in Table 8. They support our central thesis - treated domestic-listed firms experience a significant drop in EBIT share (column 1) in the postreforms period, although there was no significant increase in valuation (column 2). Columns (3)-(4) show the corresponding estimates for the sample firms without post-2003 foreign IPO, which support our central finding that the interaction terms Domestic*Reform 2003 is negative and significant only for the operating performance measure EBIT share.

Finally, we consider the extended sample period 2000-14 to see if the completion of the reforms in 2007 had a significant effect on EBIT and Tobin's Q. Given that the T\&D scores are available between 2003 and 2007 only, we assume that the 2007 value of T\&D scores (when all firms adopted the reform) persist for the remainder of our sample period, or at least does not reverse itself, which in turn allows us to specify the TD-dummy measure out to 2014 . As before, we determine the TD-dummy using a similar specification to that shown in Table 3, which yields the TD-dummy IV for 2000-14.

\section{Insert Table 9}

To obtain the clean effect of the reforms over our extended sample period of 2000-14, we drop observations in 2004-05, when the reforms are gradually being implemented and also in 200809, when the last global financial crisis occurred. These results, as summarized in Table 9, still confirm our central findings that treated domestic firms experienced a drop in EBIT share, but no significant rise in firm valuation after the adoption of the reforms.

\subsection{Differential effects of T\&D}

$\mathrm{T} \& \mathrm{D}$ reforms on their own may not necessarily resolve all the governance problems. In particular, the presence of controlling owners can often give rise to serious governance problems (Morck et al. 2005). First, controlling owners generally have more control rights than 
cash flow rights, which creates both agency and entrenchment problems. Second, controlling shareholders can divert corporate resources for private benefits using transactions within the pyramidal business group. The result is a poor utilization of resources. Third, political influence, e.g., being 'friends of powerful politicians' (endemic in Russia) is can have a great bearing on both what one controls and what one owns. Thus, in order to identify the differential effect of the reforms, we next distinguish between firms with/without controlling owners. While the government is the controlling owner in all state firms in our sample, some private firms have controlling owners with close links to Vladimir Putin.

Federal and regional governments controlled about $40 \%$ of the stock market capitalization in Russia as of 2007, compared to only $24 \%$ in $2004 .{ }^{18}$ The latter can be attributed to a number of factors: (i) Increases in minority stakes up to a controlling level (e.g. Gazprom); (ii) Acquisitions of formerly private companies (e.g. Yukos, Sibneft, VSMPO-Avisma), and (iii) Large IPOs (Rosneft, VTB). Thus, state control in various industry sectors in Russia as of 2007 measured in market capitalization are as follows: Banking: 64\%, Oil and gas: 47\%, utilities: $37 \%$. State control is typically rationalized along the lines of equity and public goods provision and also as infrastructure investments. Government intervention, however, may generate various agency issues and this can be attributed to the appointment of government representatives in the state owned corporations, transparency issues, and weak external governance mechanisms including a negligible threat of bankruptcy or a hostile takeover or of serious product market competition.

There are 11 large state firms in our sample including Gazprom, Gazpromneft, Mossenergo, Roseneft, Aeroflot, Sberbank, VIMPEL communications, VTB bank, VSMPOAvisma (where state continues to hold 51\% control even after privatization). Thus, it is fair to assume that the government acts as the controlling owner in these firms. Further, private firms can have controlling owners, which are often politically linked to Vladimir Putin (http://www.bloomberg.com/news/articles/2015-05-11/putin-s-34-billion-siberian-hoardhunted-by-cash-starved-allies) and such controlling owners can create similar governance problems as with state controlled firms. In fact, of the 59 private firms in our sample, 6 have controlling owners.

Insert Table 10

${ }^{18}$ These figures are based on estimates by Troika Dialog, Russia's oldest investment bank. 
Columns (1) and (2) show the performance estimates for firms without domestic controlling owners, while those in columns (3) and (4) show the corresponding estimates for firms with domestic controlling owners. ${ }^{19}$ It is noteworthy that in the subsample of Russian domestic firms without controlling owners, we find no decline in reported earnings, but a significant increase in stock valuation. After the implementation of the TD laws, reported earnings falls in the subsample of domestic firms with controlling owners, while no simultaneous change in valuation is observed. We believe that this drop in earnings roughly offsets the increased valuation multiplier for these owner-controlled firms, resulting in no valuation change on average. Thus, we infer that T\&D reforms do not affect the decision making in state firms or in closely held domestic firms.

\subsection{Robustness tests}

Finally, we perform a number of tests to assess the robustness of the results in Table7. These results are summarized in the Appendix Tables A1 and A2.

Dropping the very large firms: To assess whether the results we obtain are attributed to the presence of the very large firms in our sample, we examine if our baseline results in Table 7 hold for the following subsamples: i) we exclude the top $10 \%$ of the firms in terms of market capitalization (size) from our sample, ii) we exclude the top $25 \%$ of the firms in terms of size from our sample, and iii) we exclude the top $50 \%$ of the firms in terms of size from our sample. These results as summarized in Appendix Table A3 support our central finding.

$$
\text { Insert Appendix Table A3 }
$$

Dropping post-2003 foreign IPO firms: We create a sample that only includes firms that are cross-listed internationally by 2003 . There are few firms in our sample that cross-listed post-2003. When we re-estimate the model excluding the post-2003 new cross-listed firms, we find that our results remain unchanged as summarized in columns 1 and 2 of Appendix Table A4.

Insert Appendix Table A4

\footnotetext{
${ }^{19}$ Note that some of the controlling owners are foreign in our sample. We re-estimate the baseline difference-indifference model by dropping the domestic controlling owners who are more (relative to foreign controlling owners) likely to be responsible for creating private benefit of control. (see further discussion in section 4.6)
} 
Controlling for specific foreign exchanges: We observe the main foreign exchanges where Russian firms cross-list internationally to investigate whether our results are influenced by the foreign stock exchange choice. Accordingly, we control London Stock Exchange (LSE), Frankfurt Stock Exchange (Frankfurt) and New York Stock Exchange (NYSE), which are three most popular stock exchanges for cross-listed Russian firms. Our findings summarized in columns (3) and (4) of Appendix Table A4 corroborate our main findings shown in Table 6.

Dropping firms with foreign controlling owner: Earle (1998) suggests that despite the predominance of employee ownership resulting from privatization policy design, there was significant heterogeneity in Russian ownership structure in 1994. Further Estrin and Wright (1999) argued that ownership structure rapidly evolved in Russia and some other former Soviet republics in favor of outsider ownership, primarily induced by need for external finance and rapid growth of capital markets in the region (see Table 3 in Sprenger 2002). Using Orbis data, we identify the controlling owner, domestic or foreign. Table 10 shows the performance estimates with/without domestic controlling owners. We focus on the performance estimates of Russian firms without foreign controlling owner. These results, which are summarized in columns 5 and 6 of Table A4, confirm the robustness of the Table 7 estimates; namely that earnings of domestic-listed Russian firms dropped significantly, while there was no change in firm valuation in the post reform period.

\section{Concluding comments}

While the introduction of transparency and disclosure rules could lower a firm's cost of capital and may also help discipline managers, there can also be costs of disclosing too much proprietary information such as its effect on competitive advantage, managerial over-reaction, project selection and risk-taking. So the net effect of these rules ambiguous, which is one important justification for our study.

Theoretically, mandatory (as opposed to voluntary) disclosure can improve the welfare of all firms, although it may not necessarily solve the underlying manager-shareholder agency problems. The magnitude of these agency costs may determine how firm valuation changes after the implementation of the T\&D reforms.

Using a recent firm-level panel data from Russia, this study investigates whether the 2002 introduction of transparency and disclosure (T\&D) reforms and their staggered adoption by our sample firms over the 2003-07 period would necessarily raise conventional measures operating and stock performance. We exploit this natural experiment to identify a causal effect 
of the T\&D introduction and adoption on selected measures of firm performance among treated domestic listed firms (relative to the control group of cross-listed firms). In this respect, our analysis is facilitated by the availability of S\&P data on T\&D adoption scores for the top 80 listed firms in Russia for the 2003-2007period. Given the potential non-randomness of a firm's adoption of $T \& D$ rules, we instrument it using a two-stage method while also trying to minimize any bias arising from potential simultaneity as well as unobserved time trends.

Using difference-in-difference estimates, we provide new insights as to whether: (i) The reform was successful in reducing earnings management: earnings quality improved and earnings dropped among domestic Russian firms. (ii) On average, firm value remained unchanged after the reform. (iii) We identify differential effects of the reforms on domestic firms with/without controlling owners, suggesting that T\&D reforms do not affect the decision making in state owned firms or in closely held domestic firms. Earnings drop only among domestic firms with controlling owners, while firm value increases only for domestic firms without controlling owners. While this is a case study of Russian firms, the results from this study have wider implications beyond this one country, especially for firm in other postcommunist economies, where government control of private businesses often remains a fixture of economy, even in the face of radical privatization programs. 


\section{References}

Aggarwal, R., Isil, E., Stulz, R., and Williamson, R., 2007. 'Differences in governance practice between US and foreign firms: Measurement, causes, and consequences.' Working Paper, Ohio State University.

Ashbaugh, H., Collins, D. W.,La Fond, R., 2004. Corporate governance and the cost of equity capital. Working paper, University of Wisconsin-Madison

Ashbaugh-Skaife, H., Collins, D.W., La Fond, R., 2006. The effects of corporate governance on firms' credit ratings. Journal of Accounting and Economics 42,203-243.

Banerjee, S., M. Humphrey-Jenner and V. Nanda. 2013. 'Harnessing CEO Overconfidence', SSRN working paper.

Betrand, M., E. Duflo and S. Mulainathan. 2004. ' How Much Should We Trust Differences-inDifferences Estimates? Quarterly Journal of Economics, 119(1), pp. 249-275

Black, B.S., Coudert Brothers, Shin \& Kim, International Development Law Institute, 2000. Corporate governance in Korea at the millennium: enhancing international competitiveness. Final report and legal reform recommendations, consulting services for corporate governance reform in Korea.

Black, B., 2001. The corporate governance behavior and market value of Russian firms. Emerging Markets Review 2, 89-108.

Black, B.S., Love, I., Rachinsky, A., 2006. Corporate governance and firms' market values: time series evidence from Russia. Emerging Markets Review 7, 361-379.

Blasi, J.R., Shleifer, A., 1996. Corporate governance in Russia: an initial look. In: Frydman, Gray, and Rapaczynski (editors), Corporate governance in Central Europe and Russia: insiders and the state. Central European University, Budapest.

Bollard, A., 2003. Corporate governance in the financial sector. (Governor of the Reserve Bank of New Zealand, to The Annual Meeting of the Institute of Directors in New Zealand, Christchurch, 7 April 2003). http://www.rbnz.govt.nz/speeches/0132484.html

Booth, L., Aivazian, V., Demirguc-Kunt, A., Maksimovic, V., 2001. Capital structure in developing countries. The Journal of Finance 56, 87-130.

British Petroleum (BP) Statistical Review, 2007. World proved reserves of oil and natural gas, most recent estimates., U.S. Department of Energy, Energy Information Administration, Ibid.:6 -22. Accessed at www.eia.doe.gov/emeu/international/reserves.html (August 20, 2007).

Brown, L., Caylor, M., 2006. Corporate governance and firm performance. Journal of Accounting and Public Policy, 25 issue 4, 409-434.

Cole, R.A., 2008. What do we know about the capital structure of privately held firms? Evidence from the surveys of small business finances. SBA Government, SBAHQ-06-Q-0013.

Cziraki, P., P. De Goeij, L. Renneboog. 2013. 'Corporate Governance Rules and Insider Trading Profits', Review of Finance (online first) doi:10.1093/rof/rft001

Haas, R.T.A. and H.M.M. Peeters (2006), The dynamic adjustment towards target capital structures of firms in transition economies, Economics of Transition, 14(1), pp. 133-169.

Desai, M., A. Dyck and L. Zingales. 2007. Theft and Taxes. Journal of Financial Economics, 84, 591-623

Driffield, N.L., Pal, S., 2010. Evolution of capital structure in East Asia - corporate inertia or endeavours? Journal of the Royal Statistical Society (series A) 173 part 1, 1-29.

Dunrev, A. and E. H. Kim. 2005. 'To steal or not to steal: Firm attributes, legal environment and valuation', Journal of Finance.

Earle J.S. (1998), Post-Privatisation Ownership Structure and Productivity in Russian Industrial Enterprises, Stockholm Institute of Transitional Economics, Working Paper No.127.

Erixon, F., 2008. Europe's energy dependency and Russia's commercial assertiveness. European Center for International Political Economy No. 07, ISSN 1653-8994.

Errunza, V.R., Mazumdar, S.C., 2001. Privatization: a theoretical framework. Journal of International Financial Markets, Institutions and Money 11, issues 3-4, 339-362.

Estrin and Wright (1999)

Expert RA, 2004. Entrepreneurial Ethics and Corporate Governance in Russia: Investor Perceptions and Business Reality. 
Ernst and Young. 2007. 'Globalization: Global IPO Trends Report'

Financial Times. 2006.' Back in business - how Putin's allies are turning Russia into a corporate state', June 19.

Franks, J., Mayer, C., 2002. Governance as a source of managerial discipline. Research series 200205-12, National Bank of Belgium.

Goetzmann, W.N., Spiegel, M.I., Ukhov, A., 2004. Modelling and measuring Russian corporate governance: the case of Russian preferred and common shares (English version). Yale School of Management Working Papers, Yale School of Management.

Gompers, P., Ishii, J. and Metrick, A. 2003. Corporate governance and equity prices. Quarterly Journal of Economics 118, issue 1, 107-155.

Healy, P. M., and J. M. Wahlen. 1999. A review of the earnings management literature and its implications for standard setting, Accounting Horizons 13(4): 365-383.

Heinrich, A., 2006. International implications of increased state control over the Russian oil and gas sector. Eastern European Day 2006, "Russian Challenges - Between Freedom and Energy", Fribourg, Switzerland, 23 June 2006.

Herfindahl, O.C., 1950. Concentration in the U.S Steel industry. Unpublished doctoral dissertation, Columbia University.

Jensen, M.C., Meckling, W.H., 1976. Theory of the firm: managerial behaviour, agency costs and ownership structure. Journal of Financial Economics, vol. 3(4), pp. 305-360.

John, K., Senbet, L., 1998.Corporate governance and board effectiveness. Journal of Banking and Finance 22, No.4, 371-403.

Kakabadse, A., Kakabadse, N., 2001. The geopolitics of governance: the impact of contrasting philosophies. Basingstoke, Palgrave.

Karolyi, G. A. (2006), 'The World of Cross-Listings and Cross-Listings of the World: Challenging Conventional Wisdom', Review of Finance, 10, 99-152.

Klapper L., Love, I., 2002. Corporate governance, investor protection, and performance in emerging markets. Policy Research Working Paper No. 2818, World Bank, Ishington, DC. Laffont, Jean-Jacques and Jean Tirole. 1993. A Theory of Incentives in Procurement and Regulation. Cambridge: MIT Press.

La Porta, R., Lopez-De-Silanes, F., Shleifer, A., Vishny R., 2002. Investor protection and corporate valuation. The Journal of Finance 57, No. 3, 1147-1170.

La Porta, R., Lopez-de-Silanes, F., Shleifer, A., Vishny, R., 1998. Law and finance. Journal of Political Economy 106, pp. 1113-1155.

Lazareva, O., Rachinsky, A., Stepanov, S., 2007. A survey of corporate governance in Russia. CEFIR/ NES Working Paper, No. 103.

McKinsey \& Company, 2002. Global investor opinion survey: key findings. New York.

Mueller, D.C., Reardon, E.A., 1993. Rates of return on corporate investment. Southern Economic Journal 60, No. 2, 430-453.

Patel, S.A., Dallas, G., 2002. Transparency and disclosure: overview of methodology and study results United States, Standard \& Poor's.

Pistor, K., Raiser, M., Gelfer, S., 2000. Law and finance in transition economies. The Economics of Transition 8, 325-368.

Price Waterhouse Coopers. 2007. An Overview of Russian IPOs: 2005-2012. http://www.pwc.ru/en_RU/ru/capital-markets/publications/assets/a4_brochure_ipos_eng_print.pdf

Rajan, R., Zingales, L., 1995. What do we know about capital structure? Some evidence from international data. Journal of Finance 50, 1421-1460.

Roberts, J., 2004. The modern firm: organizational design for performance and growth. Oxford University Press.

Schneider, F. and D. Enste. 2002. 'Hiding in the Shadows: the Growth of the Underground Economy', Economic Issues (30), International Monetary Fund.

Sevyrkov, Oleg. 2012. 'Background Paper for OECD Russia Corporate Governance Roundtable', OECD.

Shleifer, Andrei. 1997. "Government in Transition," European Economic Review 41, pp. 385-410.

Shleifer, Andrei. 1999. "State Versus Private Ownership, Journal of Economic Perspectives. 
Shleifer, A., Vishny, R.W., 1997. A Survey of corporate governance. The Journal of Finance 52, No. 2, 737-783.

Siegel, D. 2005. 'Can foreign firms bond themselves effectively by renting U.S. securities laws?', Journal of Financial Economics, 75: 319-359.

Sprenger, C. (2002) 'Ownership and corporate governance in Russian industry: a survey', EBRD working paper no. 70, London.

Standard \& Poor. (2003). Russian Transparency and Disclosure survey 2003: positive changes in practices of Russian companies. Standard \& Poor's Governance Services.

Standard \& Poor's, 2004. Russian Transparency and Disclosure survey 2004: positive trend continues despite political obstacles. Standard \& Poor's Governance Services.

Standard \& Poor's, 2005. Russian Transparency and Disclosure survey 2005: continuing progress in transparency, but mainly among weaker disclosers. Standard \& Poor's Governance Services.

Standard \& Poor's, 2006. Transparency and Disclosure by Russian companies 2006: modest progress amid the IPO deal. Standard \& Poor's Governance Services.

Standard \& Poor's, 2007. Transparency and Disclosure by Russian companies 2007: high turnover in the top 10. Standard \& Poor's Governance Services.

Tobin, J., 1969. A general equilibrium approach to monetary theory. Journal of Money Credit and Banking 1, No. 1, 15-29.

Tobin, J., Brainard, W.C., 1977. Asset markets and the cost of capital. Economic Progress, Private Values and Public Policy.

Treisman, D. 2000. 'Decentralization, Tax Evasion and the Underground Economy: A Model with Evidence from Russia', mimeo, University of California Los Angeles.

Yeoh, P., 2007. Corporate governance models: is there a right one for transition economies in Central and Eastern Europe? Managerial Law 49 issue 3, 57-75.

Yu, F., 2005. Accounting transparency and the term structure of credit spreads. Journal of Financial Economics 75, 53-84. 


\section{Table 1: Descriptive statistics 2000-07}

We consider two measures of firm performance, namely, Tobin's Q ratio defined as (market capital plus book value of debt) as a share of total assets and earnings before interest and taxes (EBIT) as a share of total assets. The four T\&D indices refer to financial, ownership, board and management and a composite index obtained by using factor analysis. All firms are domestically listed while only a subset of these listed firms is also listed internationally. We construct Herfindahl index as a measure of firm

concentration (competition); a value of the index above 180 indicates high concentration. We also show descriptive statistics for some of the additional explanatory variables including age of the firm and also firm size (measured by log of total assets and also by the top three quartile values). T\&D scores are available only for $2003-2007$. T\&D dummy is the binary variable that takes a value 1 when T\&D scores $>0$ and 0 otherwise for 2000-07.

\begin{tabular}{lccc}
\hline \multicolumn{1}{c}{ Variable } & \multicolumn{2}{c}{ All industries } \\
& Firms & Mean & Std. Dev. \\
\hline Performance/Firm value proxies & & & \\
Tobin's Q & 64 & 1.60 & 1.29 \\
EBIT/Assets & 70 & 0.13 & 0.10 \\
Reform dummy & & & \\
TD-dummy & 70 & 0.36 & 0.48 \\
TD- scores 2003-07[1] & & & \\
TD-overall & 70 & 0.52 & 0.16 \\
TD financial \& operational & 70 & 0.54 & 0.18 \\
TD ownership & 70 & 0.52 & 0.18 \\
TD board \& shareholders & 70 & 0.48 & 0.16 \\
Stock market listing & & & \\
Only domestic listing & 70 & 0.81 & 0.39 \\
Foreign listing & 70 & 0.19 & 0.39 \\
Firm concentration & & & \\
Herfindahl index & 70 & 94 & 27.06 \\
Other characteristics & & & \\
Ln of total assets & 70 & 14.45 & 1.72 \\
Size-Q4 & 70 & 0.47 & 0.49 \\
Size-Q3 & 70 & 0.17 & 0.38 \\
Size-Q2 & 70 & 0.18 & \\
Firm age & & 19.57 & \\
\hline
\end{tabular}




\section{Table 2: Mean comparisons of selected characteristics of foreign and domestic listed firms}

Columns 1-3 of this table compare the means of selected characteristics of foreign and domestic listed firms in our sample. We test the null hypothesis that means of the selected variables are the same for domestic and listed firms in our sample. $* \mathrm{p}<0.10 ; * * p<0.05 ; * * * p<0.01$. Column (4) shows the Pearson's chi-square test for equality of medians by domestic/cross-listed firms.

\begin{tabular}{|c|c|c|c|c|}
\hline Variables & $\begin{array}{c}\text { Cross-listed } \\
\text { (Control group) } \\
\text { Mean (median) } \\
\end{array}$ & $\begin{array}{c}\text { Domestic-listed } \\
\text { (Treatment group) } \\
\text { Mean (Median) }\end{array}$ & $\begin{array}{c}\text { Equality of Mean } \\
\text { by domestic/foreign } \\
\text { T-statistic }\end{array}$ & $\begin{array}{c}\text { Equality of median by } \\
\text { domestic/foreign } \\
\text { Chi-square (p-value) }\end{array}$ \\
\hline Size (log of total assets) 2000-07 & $13.85(13.2394)$ & $14.49(14.15)$ & $-3.194 * * *$ & $7.0957(0.008)^{* * *}$ \\
\hline Age (years) 2000-07 & $7.3(4)$ & $20.21(10)$ & $-5.516 * * *$ & $13.7901(0.000)^{* * *}$ \\
\hline Intangibility 2000-07 & $10.38(0.4197)$ & $3.14(1.008)$ & $4.1418 * * *$ & $7.0957(0.008) * * *$ \\
\hline Tobin's Q 2000-07 & $2.63(1.7495)$ & $1.17(1.3855)$ & $3.745 * * *$ & $3.7290(0.053)^{* *}$ \\
\hline EBIT to total assets $2000-07$ & $0.1(0.1048)$ & $0.12(0.1189)$ & -1.437 & $0.1645(0.685)$ \\
\hline Tobin's Q - pre 2003 & 0.93 & 0.73 & 0.963 & $0.1094(0.74)$ \\
\hline EBIT to total assets - pre 2003 & 0.07 & 0.11 & -1.124 & $1.2920(0.256)$ \\
\hline Tobin's Q - post 2003 & 2.87 & 1.69 & $4.372 * * *$ & $7.9184(0.005)^{* * *}$ \\
\hline EBIT to total assets - post 2003 & 0.12 & 0.14 & -0.664 & $0.1078(0.745)$ \\
\hline Tobin's Q - pre 2004 & 1.41 & 1.15 & 0.7257 & $0.2549(0.614)$ \\
\hline EBIT to total assets - pre 2004 & 0.08 & 0.12 & -1.5943 & $0.2272(0.664)$ \\
\hline Tobin's Q - post 2004 & 3.03 & 1.77 & $4.2033 * * *$ & $2.9954(0.088)$ \\
\hline EBIT to total assets - post 2004 & 0.13 & 0.14 & -0.6246 & $0.1078(0.743)$ \\
\hline
\end{tabular}




\section{Table 3: First stage estimates of adoption of transparency and disclosure}

This table shows the estimates of T\&D scores (2003-07) and the associated binary variable TD-dummy (2000-07). In addition to various firm characteristics like firm size, age, R\&D share and Herfindahl index, the identifying variables are liability ratio, growth of sales and law and order (e.g., Berglof and Pajuste, 2005). The TD-dummy (or TD-dummy-IV) takes the value 1 if the firm has positive T\&D score (characteristic adjusted positive T\&D score) and takes the value 0 otherwise. It is thus an index of adoption of the T\&D reform. TD_all_gtmed is a second binary variable that takes a value 1 if the firm's T\&D score is greater than the median value of the sample distribution and is zero otherwise. Robust standard errors in parentheses; *** $\mathrm{p}<0.01, * * \mathrm{p}<0.05, * \mathrm{p}<0.1$.

\begin{tabular}{lcc}
\hline & $(1)$ & $(2)$ \\
VARIABLES & TD-Dummy & TD_all_gtmed \\
\hline \multirow{2}{*}{ Law \& order } & $0.966^{* * *}$ & $0.440^{* *}$ \\
& $(0.203)$ & $(0.210)$ \\
Total liability to total assets & $-0.863^{* *}$ & -0.535 \\
& $(0.348)$ & $(0.369)$ \\
Growth of sales & -0.00437 & 0.00146 \\
& $(0.00804)$ & $(0.00698)$ \\
Firm age & $0.286^{* *}$ & $0.441^{* * *}$ \\
& $(0.129)$ & $(0.135)$ \\
Ln(Total assets) & -0.0322 & 0.0635 \\
& $(0.164)$ & $(0.131)$ \\
Intangibility & -0.0233 & $0.0550^{* *}$ \\
& $(0.0156)$ & $(0.0220)$ \\
Herfindahl & $0.332^{*}$ & $0.477 * *$ \\
& $(0.175)$ & $(0.220)$ \\
Constant & $747.3 * *$ & $1,067^{* * *}$ \\
& $(289.6)$ & $(319.8)$ \\
Firm and Year FE & Yes & Yes \\
No of firms & 58 & 58 \\
R-squared & 0.644 & 0.369 \\
\hline
\end{tabular}




\section{Table 4: Performance estimates in the pre-reform period}

This table shows the performance of only domestic listed Russian firms prior to the implementation of Russian corporate governance reform (CG Reform) in 2002/2003. The variable "Domestic" is a dummy variable - takes the value 1 if the firm is listed only in Russian exchanges and it takes 0 if the firm is listed in both Russian exchange and one/many foreign exchanges (cross-listed). Robust standard errors in parentheses $* * * \mathrm{p}<0.01, * *$ $\mathrm{p}<0.05, * \mathrm{p}<0.1$

\begin{tabular}{ccccc}
\hline & \multicolumn{2}{c}{ Pre-introduction } & \multicolumn{2}{c}{ Pre-adoption } \\
VARIABLES & $(1)$ EBIT share & (2)Tobin's Q & (3)EBIT share & (4)Tobin's Q \\
\hline \multirow{2}{*}{ Domestic } & $0.0462^{*}$ & -2.310 & $0.0530^{* *}$ & -1.018 \\
& $(0.0273)$ & $(2.443)$ & $(0.0261)$ & $(1.428)$ \\
Firm age & -0.000149 & -0.00100 & 0.00598 & $-0.418^{* * *}$ \\
& $(0.000248)$ & $(0.00521)$ & $(0.00747)$ & $(0.136)$ \\
Ln(Total Assets) & -0.000373 & $-0.644^{*}$ & -0.000145 & -0.00375 \\
& $(0.00727)$ & $(0.326)$ & $(0.000262)$ & $(0.00279)$ \\
Intangibility & -0.000458 & $0.132^{*}$ & 0.000165 & 0.0626 \\
& $(0.00233)$ & $(0.0706)$ & $(0.00318)$ & $(0.0415)$ \\
Constant & 0.0446 & $17.07^{* *}$ & 0.00157 & $8.673 * * *$ \\
& $(0.0978)$ & $(7.524)$ & $(0.0990)$ & $(2.012)$ \\
Yes & Yes & Yes & Yes \\
Industry and Year dummies & Yes & Yes & Yes & Yes \\
Industry*Year dummies & 56 & 51 & 56 & 51 \\
No of firms & 0.137 & 0.283 & 0.050 & 0.090 \\
R-squared & & & & \\
\hline
\end{tabular}




\section{Table 5: Test of parallel trend in treatment and control groups}

Robust standard errors in parentheses; *** $\mathrm{p}<0.01, * * \mathrm{p}<0.05, * \mathrm{p}<0.1$ The table shows that the parallel trends in the outcome variables (Tobin's Q and EBIT/Assets) were the same for both the treatment and the control groups in our sample as highlighted in the statistical insignificance of the interaction terms between domestic and year dummies.

\begin{tabular}{|c|c|c|}
\hline VARIABLES & (1)Tobin's Q & (1)EBIT/Assets \\
\hline \multirow[t]{2}{*}{ Domestic } & 0.0684 & $0.105 * *$ \\
\hline & $(0.129)$ & $(0.0442)$ \\
\hline \multirow[t]{2}{*}{ Year_2001 } & -1.062 & 0.0241 \\
\hline & $(0.660)$ & $(0.0486)$ \\
\hline \multirow[t]{2}{*}{ Year_2002 } & $-1.360 * *$ & 0.0442 \\
\hline & $(0.675)$ & $(0.0477)$ \\
\hline \multirow[t]{2}{*}{ Year_2003 } & -0.311 & 0.0694 \\
\hline & $(0.946)$ & $(0.0552)$ \\
\hline \multirow[t]{2}{*}{ Year_2004 } & 0.855 & 0.0614 \\
\hline & $(1.151)$ & $(0.0676)$ \\
\hline \multirow[t]{2}{*}{ Year_2005 } & 1.547 & $0.101 *$ \\
\hline & $(1.135)$ & $(0.0528)$ \\
\hline \multirow[t]{2}{*}{ Year_2006 } & 0.412 & $0.0897 *$ \\
\hline & $(0.922)$ & $(0.0491)$ \\
\hline \multirow[t]{2}{*}{ Year_2007 } & $-1.460 * *$ & $0.0857 *$ \\
\hline & $(0.669)$ & $(0.0470)$ \\
\hline \multirow[t]{2}{*}{ Domestic*Y2001 } & Dropped & -0.0347 \\
\hline & & $(0.0577)$ \\
\hline \multirow{2}{*}{ Domestic*Y2002 } & -0.186 & -0.0818 \\
\hline & $(0.222)$ & $(0.0542)$ \\
\hline \multirow[t]{2}{*}{ Domestic*Y2003 } & -0.764 & -0.115 \\
\hline & $(0.713)$ & $(0.0655)$ \\
\hline \multirow{2}{*}{ Domestic*Y2004 } & -1.072 & -0.0789 \\
\hline & $(0.686)$ & $(0.0727)$ \\
\hline \multirow[t]{2}{*}{ Domestic*Y2005 } & -1.426 & -0.110 \\
\hline & $(0.978)$ & $(0.0597)$ \\
\hline \multirow[t]{2}{*}{ Domestic*Y2006 } & -0.924 & -0.0810 \\
\hline & $(0.943)$ & $(0.0552)$ \\
\hline \multirow[t]{2}{*}{ Domestic*Y2007 } & -0.739 & -0.107 \\
\hline & $(0.687)$ & $(0.532)$ \\
\hline \multirow[t]{2}{*}{ Constant } & $2.213 * * *$ & 0.0443 \\
\hline & $(0.660)$ & $(0.0386)$ \\
\hline No of firms & 53 & 58 \\
\hline R-squared & 0.256 & 0.044 \\
\hline
\end{tabular}

Robust standard errors in parentheses

$* * * \mathrm{p}<0.01, * * \mathrm{p}<0.05, * \mathrm{p}<0.1$ 


\section{Table 6. Effect of the reform on earnings quality (EQ)}

This table shows the Group-FE DID estimates of earnings quality of Russian domestic listed firm performance vis-à-vis Russian cross-listed firms. We use three measures of earnings quality: EQ1 is the ratio of EBIT to cash flow while EQ2 is the ratio of sd of EBIT to sd of cash flow. EQ3 is the ratio of sd of EBIT to mean cash flow while EQ4 is the ratio of operating accrual to total assets. There is evidence that the EQ1 and EQ2 was significantly higher among domestic firms after the reform. Robust standard errors in parentheses; $* * * \mathrm{p}<0.01, * * \mathrm{p}<0.05$, $* \mathrm{p}<0.1$

\begin{tabular}{lcccc}
\hline & $(1)$ & $(2)$ & $(3)$ & $(4)$ \\
VARIABLES & EQ1 & EQ2 & EQ3 & EQ4 \\
\hline & & & & \\
TD-Dummy-IV & $-2.129 * *$ & $-0.678^{*}$ & -0.242 & $-25.59^{* *}$ \\
& $(1.055)$ & $(0.354)$ & $(0.177)$ & $(12.54)$ \\
Domestic & -2.939 & 1.406 & $-4.201^{* * *}$ & -7.512 \\
& $(3.804)$ & $(2.738)$ & $(1.291)$ & $(6.553)$ \\
Domestic*TD-Dummy-IV & $2.098^{* *}$ & $0.684^{*}$ & 0.243 & $18.05^{*}$ \\
& $(1.061)$ & $(0.349)$ & $(0.174)$ & $(10.45)$ \\
Firm age & $0.157^{* *}$ & 0.0551 & $0.0770^{* * *}$ & 0.0101 \\
& $(0.0724)$ & $(0.0427)$ & $(0.0240)$ & $(0.0163)$ \\
Ln(Total Assets) & $4.073^{*}$ & $3.958^{*}$ & $2.000^{* *}$ & $3.104 * * *$ \\
& $(2.252)$ & $(2.223)$ & $(0.998)$ & $(1.113)$ \\
Intangibility & 1.876 & 0.829 & -0.273 & $-0.354^{* *}$ \\
& $(1.145)$ & $(0.867)$ & $(0.472)$ & $(0.148)$ \\
Constant & $-63.63^{* *}$ & $-59.07 * *$ & $-21.77 *$ & $-43.34^{* *}$ \\
& $(28.96)$ & $(29.36)$ & $(13.16)$ & $(17.00)$ \\
Industry dummy & Yes & Yes & Yes & Yes \\
Year dummy & Yes & Yes & Yes & Yes \\
Industry*Year & Yes & Yes & Yes & Yes \\
Firms & 56 & 56 & 58 & 46 \\
R-squared & 0.191 & 0.177 & 0.077 & 0.237 \\
\hline
\end{tabular}




\section{Table 7: Group FE DID estimates of firm performance}

This table includes Group fixed effect based DID estimates of Russian domestic-listed firm performance vis-à-vis Russian cross-listed firms. Here we include the dummy for the domestic=listed Russian firms ("Domestic") and also interact it with the firm-level reform adoption variable (TD-Dummy or its instrumental version: TD-Dummy-IV). The variable "Domestic" is a dummy variable - takes the value 1 if the firm is listed only in Russian exchanges and it takes 0 if the firm is listed in both Russian exchange and one/many foreign exchanges (cross-listed). The TD-Dummy (or TD-Dummy IV) takes the value 1 if the firm has positive $T \& D$ score (characteristic adjusted positive $T \& D$ score) and takes the value 0 otherwise. Tobin's Q and EBIT/Assets are the dependent variables as proxies for operating performance and firm valuation. Robust standard errors in parentheses; *** $\mathrm{p}<0.01, * * \mathrm{p}<0.05$, $* \mathrm{p}<0.1$.

\begin{tabular}{lcccc}
\hline & $(1)$ & $(2)$ & $(3)$ & $(4)$ \\
VARIABLES & Tobin's Q & EBIT share & Tobin's Q & EBIT share \\
\hline & -1.862 & 0.0239 & & \\
TD-Dummy & $(1.752)$ & $(0.0347)$ & & \\
Domestic & -2.179 & $0.0477 *$ & -0.573 & 0.00504 \\
& $(1.956)$ & $(0.0264)$ & $(0.381)$ & $(0.0193)$ \\
Domestic $\times$ TD-Dummy & 2.011 & -0.0435 & & \\
TD-Dummy-IV & $(2.010)$ & $(0.0335)$ & & \\
& & & -0.0842 & $0.00662 * * *$ \\
Domestic $\times$ TD-Dummy-IV & & & $(0.180)$ & $(0.00185)$ \\
& & & 0.293 & $-0.00698 * * *$ \\
Firm age & & & $(0.273)$ & $(0.00182)$ \\
& -0.000650 & $1.49 \mathrm{e}-05$ & -0.00240 & $-1.28 \mathrm{e}-05$ \\
Ln(Total Assets) & $(0.00232)$ & $(0.000188)$ & $(0.00246)$ & $(0.000206)$ \\
& $-0.502 * * *$ & $0.00827 *$ & $-0.441 * * *$ & 0.00813 \\
Intangibility & $(0.142)$ & $(0.00493)$ & $(0.119)$ & $(0.00523)$ \\
& $0.0540^{* * *}$ & -0.000680 & 0.00914 & -0.000911 \\
Constant & $(0.0204)$ & $(0.00109)$ & $(0.0269)$ & $(0.00116)$ \\
& $15.06^{* * *}$ & -0.0745 & $16.27 * * *$ & -0.0308 \\
Industry dummy & $(5.768)$ & $(0.0694)$ & $(5.433)$ & $(0.0749)$ \\
Year dummy & Yes & Yes & Yes & Yes \\
Industry*Year dummy & Yes & Yes & Yes & Yes \\
No of firms & Yes & Yes & Yes & Yes \\
R-squared & 51 & 56 & 51 & 56 \\
\hline & 0.267 & 0.126 & 0.340 & 0.150 \\
\hline & & & &
\end{tabular}


Table 7a: Comparisons of total assets before and after the reform

\begin{tabular}{lcccc}
\hline Variables & $\begin{array}{c}\text { Pre-reform } \\
(\mathbf{2 0 0 0 - 0 2}) \\
\text { Mean }\end{array}$ & $\begin{array}{c}\text { Post-reform } \\
\mathbf{( 2 0 0 3 - 0 7 )} \\
\text { Mean }\end{array}$ & $\begin{array}{c}\text { Equality of Means } \\
\text { T-statistic }\end{array}$ & $\begin{array}{c}\text { Equality of Median } \\
\text { Chi-square (p value) } \\
\text { Before/after 2003-07 }\end{array}$ \\
\hline Total Assets & 6714608 & 8143398 & -0.5724 & $0.009(0.924)$ \\
Ln[Total Assets] & 14.26 & 14.33 & -0.3374 & $0.009(0.924)$ \\
Growth in Total Assets & 0.35 & 0.64 & -0.8524 & $2.3381(01.26)$ \\
& & & & \\
Variables & $\mathbf{( 2 0 0 0 - 0 3 )}$ & $\mathbf{( 2 0 0 4 - 0 7 )}$ & T-statistic & Before/after 2004-07 \\
Total Assets & 6261209 & 8626565 & -1.0797 & $0.3699(0.543)$ \\
Ln[Total Assets] & 14.17 & 14.39 & 1.2117 & $0.3699(0.543)$ \\
Growth in Total Assets & 0.79 & 0.53 & 0.7845 & $12.6175(0.000)$ \\
\hline
\end{tabular}

Table 7b: Invariance of $\log$ of total assets after the reform

\begin{tabular}{lccc}
\hline VARIABLES & $\begin{array}{c}(1) \\
\text { Ln(total } \\
\text { assets })\end{array}$ & $\begin{array}{c}(2) \\
\text { Ln(total } \\
\text { assets) }\end{array}$ & $\begin{array}{c}(3) \\
\text { Ln(total } \\
\text { assets) }\end{array}$ \\
\hline TD-Dummy IV & 0.0218 & & \\
Reform 2003 & $(0.0221)$ & & \\
& & -0.298 & \\
Reform 2004 & $(0.375)$ & \\
& & & -0.321 \\
Constant & $14.23^{* * *}$ & $13.90^{* * *}$ & $(0.364)$ \\
& $(0.615)$ & $(0.307)$ & $(0.307 * *$ \\
Industry dummy & Yes & Yes & Yes \\
Year dummy & Yes & Yes & Yes \\
& & & 70 \\
No of firms & 56 & 70 & 70.114 \\
R-squared & 0.169 & 0.114 & 0.14 \\
\hline
\end{tabular}

Robust standard errors in parentheses $* * * \mathrm{p}<0.01, * * \mathrm{p}<0.05, * \mathrm{p}<0.1$ 
Table 7c. Performance estimates for cross-listed firms

\begin{tabular}{lcc}
\hline & $(1)$ & $(2)$ \\
VARIABLES & Tobin's Q & ebit_ta \\
\hline TD-Dummy IV & -2.737 & 0.0549 \\
& $(4.691)$ & $(0.0392)$ \\
Firm age & $-1.531 * * *$ & $0.0555^{* *}$ \\
& $(0.526)$ & $(0.0209)$ \\
Ln(Total Assets) & 0.0144 & -0.00231 \\
& $(0.0859)$ & $(0.00204)$ \\
Intangibility & 0.575 & -0.0191 \\
& $(0.549)$ & $(0.0124)$ \\
Constant & $24.15 * * *$ & $-0.624 * *$ \\
& $(6.232)$ & $(0.267)$ \\
Industry dummy & Yes & Yes \\
Year dummy & Yes & Yes \\
Industry*Year & Yes & Yes \\
dummy & & \\
No of firms & 6 & 8 \\
R-squared & 0.116 & 0.214 \\
\hline
\end{tabular}

Robust standard errors in parentheses $* * * \mathrm{p}<0.01, * * \mathrm{p}<0.05, * \mathrm{p}<0.1$ 
Table 8: Group FE estimates using alternative reform introduction dummy

This table includes Group-FE DID estimates of Russian domestic listed firm performance vis-à-vis Russian cross-listed firms with broad based reform dummy. Our "treatment group" consists of firms that are listed only in Russian domestic stock exchange. Our "control group" consists of firms that are cross-listed: listed in at least one Russian domestic stock exchange and at least one foreign stock exchange. Here we include the dummy for the domestic listed Russian firms ("Domestic") and also interact it with the reform dummy (Reform 2003). The variable "Domestic" is a dummy variable - takes the value 1 if the firm is listed only in Russian exchanges and it takes 0 if the firm is listed in both Russian exchange and one/many foreign exchanges (cross-listed). The Reform 2003 takes the value 1 if the year is $>=2003$ and takes the value 0 otherwise. Tobin's Q denotes and EBIT/Assets are the dependent variables as proxies for operating performance and firm valuation. Robust standard errors in parentheses; $* * * \mathrm{p}<0.01, * * \mathrm{p}<0.05, * \mathrm{p}<0.1$.

\begin{tabular}{lcccc}
\hline & \multicolumn{2}{c}{ All firms } & \multicolumn{2}{c}{ Without post-2003 foreign } \\
& $(1)$ & $(2)$ & $(3)$ & $(4)$ \\
VARIABLES & TQ2n & ebit_ta & TQ2n & ebit_ta \\
\hline \multirow{2}{*}{ Reform 2003 (year>=2003) } & -3.568 & 0.0361 & -4.098 & $0.0648^{*}$ \\
& $(3.990)$ & $(0.0321)$ & $(4.054)$ & $(0.0330)$ \\
Domestic & -3.458 & $0.0592^{* *}$ & -3.176 & $0.0766^{* *}$ \\
& $(3.724)$ & $(0.0272)$ & $(3.618)$ & $(0.0304)$ \\
Domestic*Reform 2003 & 3.319 & -0.0414 & 3.603 & $-0.0737 *$ \\
& $(3.688)$ & $(0.0336)$ & $(3.586)$ & $(0.0375)$ \\
Firm age & -0.00183 & $-1.39 \mathrm{e}-05$ & 0.00130 & 0.000104 \\
& $(0.00169)$ & $(0.000183)$ & $(0.00217)$ & $(0.000296)$ \\
Ln(Total Assets) & $-0.342^{* * *}$ & 0.00784 & $-0.340 * * *$ & 0.000613 \\
Intangibility & $(0.0891)$ & $(0.00480)$ & $(0.0984)$ & $(0.00538)$ \\
& $0.0354^{* *}$ & -0.000781 & $0.0331^{* *}$ & 0.000169 \\
Constant & $(0.0138)$ & $(0.00108)$ & $(0.0147)$ & $(0.00118)$ \\
& $10.45^{* * *}$ & -0.0455 & $10.58^{* * *}$ & 0.0503 \\
Industry dummy & $(3.709)$ & $(0.0672)$ & $(3.917)$ & $(0.0759)$ \\
Industry*Year dummy & Yes & Yes & Yes & Yes \\
& Yes & Yes & Yes & Yes \\
No of firms & 51 & 56 & 43 & 46 \\
R-squared & 5.172 & 0.113 & 0.179 & 0.077 \\
\hline
\end{tabular}




\section{Table 9. Performance estimates for the extended sample 2000-14}

This Table shows the DID estimates of selected performance measures for an extended sample of 200014 with a view to identify the effect of the completion of the reform in 2007 on performance over 200014 after dropping the initial reform years 2004-05 (columns 1 and 2) and also the financial crisis year 2008 (columns 3 and 4). These estimates also drop the firms that had foreign IPO in the post-2003 years. In this case, we assume that the 2007 values of adoption of the reform persists in the post reform years 2007-2014 which in turn allows us to obtain the TD-dummy- IV07 using the same specification as in Table 3. Results support our earlier results that domestic firms had lower EBIT after the completion of the reform. Robust standard errors in parentheses; *** $\mathrm{p}<0.01, * * \mathrm{p}<0.05,{ }^{*} \mathrm{p}<0.1$.

\begin{tabular}{lcc}
\hline & \multicolumn{2}{c}{$\begin{array}{c}\text { Completion of reform: } \\
\text { before/after 2007 }\end{array}$} \\
\hline VARIABLES & (1)Tobin's Q & $\begin{array}{c}(2) \text { EBIT } \\
\text { share }\end{array}$ \\
\hline & & \\
Domestic & -1.612 & $0.0575^{* *}$ \\
& $(2.400)$ & $(0.0249)$ \\
TD-Dummy-IV07 & -0.662 & $0.0252^{* *}$ \\
& $(0.880)$ & $(0.0113)$ \\
Domestic*TD-Dummy-IV07 & 0.656 & $-0.0256^{* *}$ \\
& $(0.804)$ & $(0.0113)$ \\
Firm age & 0.00259 & 0.000106 \\
& $(0.00501)$ & $(0.000319)$ \\
Ln(Total Assets) & $-0.458^{* *}$ & -0.00339 \\
& $(0.180)$ & $(0.00663)$ \\
Intangibility & 0.0477 & 0.000956 \\
& $(0.0358)$ & $(0.00141)$ \\
Constant & $10.57 * * *$ & 0.114 \\
& $(3.094)$ & $(0.0901)$ \\
Other control variables & Yes & Yes \\
Industry dummy & Yes & Yes \\
Industry*Year dummy & Yes & Yes \\
Firms & 41 & 46 \\
R-squared & 0.149 & 0.116 \\
\hline
\end{tabular}


Table 10 - estimates for firms without/with controlling owners

This table shows the Group FE DID estimates of Russian domestic listed firm performance visà-vis Russian cross-listed firms after we split all firms in private and state-controlled firms. As in Table 6, we include the dummy for the domestic listed Russian firms ("Domestic") and also interact it with the firm-level reform adoption variable (TD-Dummy instrumental version). The variable "Domestic" is a dummy variable - takes the value 1 if the firm is listed only in Russian exchanges and it takes 0 if the firm is listed in both Russian exchange and one/many foreign exchanges (cross-listed). The TD-Dummy-IV is the predicted value of TD-dummy using Table 3 column 1 estimates. All continuous right hand side variables are lagged by one year. Tobin's Q and EBIT/Assets are the dependent variables as proxies for operating performance and firm valuation. Robust standard errors in parentheses; *** $\mathrm{p}<0.01, * * \mathrm{p}<0.05, * \mathrm{p}<0.1$.

\begin{tabular}{lcccc}
\hline & \multicolumn{2}{c}{ Without domestic controlling } & \multicolumn{2}{c}{ With domestic controlling owners } \\
owners & $(1)$ & $(2)$ & $(3)$ & $(4)$ \\
VARIABLES & Tobin's Q & ebit_ta & Tobin's Q & ebit_ta \\
\hline & & & & \\
TD-Dummy-IV & $-4.159^{* * *}$ & 0.0308 & 0.498 & $0.110^{* * *}$ \\
& $(1.148)$ & $(0.0461)$ & $(0.337)$ & $(0.0355)$ \\
Domestic & $-3.503^{* * *}$ & 0.0251 & $1.226^{* * *}$ & $0.0701^{* *}$ \\
& $(0.837)$ & $(0.0324)$ & $(0.373)$ & $(0.0314)$ \\
Domestic * TD-Dummy-IV & $3.650^{* * *}$ & -0.0286 & 0.283 & $-0.108^{* *}$ \\
& $(1.167)$ & $(0.0466)$ & $(0.554)$ & $(0.0477)$ \\
Constant & $7.751^{* * *}$ & $-0.171^{*}$ & $7.454 * * *$ & 0.0315 \\
& $(2.371)$ & $(0.0939)$ & $(0.871)$ & $(0.0936)$ \\
Other variables & Yes & Yes & Yes & Yes \\
Industry & Yes & Yes & Yes & Yes \\
Year & Yes & Yes & Yes & Yes \\
Industry*Year & Yes & Yes & Yes & Yes \\
No of firms & 38 & 40 & 16 & 17 \\
R-squared & 0.175 & 0.206 & 0.309 & 0.093 \\
\hline
\end{tabular}




\section{APPENDIX}

\section{Table A1: Establishing identifying restrictions}

Note that the three instruments, namely, law and order, total liability to total assets and growth of sales are individually statistically insignificant to explain EBIT share and Tobin'sQ in our sample. Robust standard errors in parentheses; ${ }^{* * *} \mathrm{p}<0.01,{ }^{* *} \mathrm{p}<0.05, * \mathrm{p}<0.1$

\begin{tabular}{lcc}
\hline & $(1)$ & $(2)$ \\
VARIABLES & Ebit share & Tobin's Q \\
\hline \multirow{2}{*}{ Law \& order } & -0.0688 & 0.0205 \\
& $(0.0578)$ & $(0.0197)$ \\
Total liability to total assets & 0.0925 & -0.0484 \\
& $(0.0723)$ & $(0.0387)$ \\
Growth of sales & -0.00227 & -0.0375 \\
& $(0.00231)$ & $(0.0236)$ \\
TD-Dummy IV & $0.295^{* *}$ & -0.119 \\
& $(0.127)$ & $(0.122)$ \\
domestic & $0.0507 * *$ & -0.0305 \\
& $(0.0225)$ & $(0.0311)$ \\
Domestic* TD-Dummy IV & $-0.159 *$ & 0.0556 \\
& $(0.0881)$ & $(0.0773)$ \\
Lnta & 0.00465 & $-0.781 * * *$ \\
& $(0.00800)$ & $(0.255)$ \\
Intangibility ratio & -0.000145 & -0.0622 \\
& $(0.000900)$ & $(0.0702)$ \\
Constant & 0.181 & $11.433 * * *$ \\
& $(0.195)$ & $(4.914)$ \\
Industry dummy & Yes & Yes \\
Industry*Year dummy & Yes & Yes \\
No of firms & 56 & 51 \\
R-squared & 0.165 & 0.242 \\
\hline
\end{tabular}

Table A2. Instrument validity test

This Table shows that the instrument is uncorrelated with the estimated residuals of the two performance indices. Robust standard errors in parentheses; $* * * \mathrm{p}<0.01, * * \mathrm{p}<0.05, * \mathrm{p}<0.1$.

\begin{tabular}{lcc}
\hline & $(1)$ & $(2)$ \\
VARIABLES & Resid(EBIT share) & Resid(Tobin's Q) \\
\hline & & \\
TD-Dummy_IV & -0.0193 & 1.472 \\
& $(0.0887)$ & $(1.198)$ \\
Constant & -0.0249 & 2.160 \\
& $(0.0346)$ & $(1.951)$ \\
Industry dummy & Yes & Yes \\
Year dummy & Yes & Yes \\
Observations & 325 & 297 \\
R-squared & 0.006 & 0.055 \\
\hline
\end{tabular}




\section{Table A3: Group FE estimates for smaller firms}

In this table we obtain DID estimates of selected firm performance measures for smaller firms. We drop top $10 \%$, top $25 \%$ and top $50 \%$ of Russian firms - both cross-listed and only domestic listed. Other control variables are as in Table 4. The variable "Domestic" is a dummy variable - takes the value 1 if the firm is listed only in Russian exchanges and it takes 0 is the firm is listed in both Russian exchange and one/many foreign exchanges (cross-listed). The TDdummy (or TD-dummy-IV) takes the value 1 if the firm has positive T\&D score (characteristic adjusted positive $\mathrm{T} \& \mathrm{D}$ score) and takes the value 0 otherwise. Other control variables are as in Table 6. Tobin's $\mathrm{Q}$ and EBIT/Assets are the dependent variables as proxies for operating performance and firm valuation. Robust standard errors are in parentheses: $* * * \mathrm{p}<0.01, * *$ $\mathrm{p}<0.05, * \mathrm{p}<0.1$.

\begin{tabular}{lcccc}
\hline & \multicolumn{2}{c}{ Excluding top 50\% } & \multicolumn{2}{c}{ Excluding top 25\% } \\
\hline \multicolumn{1}{c}{ VARIABLES } & $(1)$ & $(2)$ & $(3)$ & $(4)$ \\
& Tobin's Q & EBIT share & Tobin's Q & EBIT share \\
\hline \multirow{2}{*}{ TD-Dummy-IV } & & & & \\
& 0.108 & $0.00661^{* *}$ & 0.0357 & $0.00622^{* * *}$ \\
Domestic & $(0.171)$ & $(0.00261)$ & $(0.148)$ & $(0.00203)$ \\
& -0.142 & 0.0243 & -0.378 & 0.00496 \\
Domestic $\times$ TD-Dummy-IV & $(0.380)$ & $(0.0202)$ & $(0.342)$ & $(0.0216)$ \\
& 0.321 & $-0.00582^{* * *}$ & 0.295 & $-0.00640 * * *$ \\
Firm age & $(0.283)$ & $(0.00199)$ & $(0.283)$ & $(0.00198)$ \\
& 0.00732 & $-1.73 \mathrm{e}-05$ & 0.00122 & 0.000133 \\
Ln(Total Assets) & $(0.00528)$ & $(0.000237)$ & $(0.00334)$ & $(0.000225)$ \\
& $-0.676^{*}$ & $0.0640^{* * *}$ & $-1.078^{* * *}$ & $0.0402^{* * *}$ \\
Intangibility & $(0.374)$ & $(0.0195)$ & $(0.242)$ & $(0.0142)$ \\
& $-1.847^{*}$ & $-0.195 * * *$ & 0.175 & $-0.0459^{* * *}$ \\
Constant & $(1.039)$ & $(0.0434)$ & $(0.369)$ & $(0.0147)$ \\
& $23.72 * * *$ & $-0.648^{* *}$ & $25.64 * * *$ & $-0.405^{* *}$ \\
Industry dummy & $(7.477)$ & $(0.249)$ & $(5.822)$ & $(0.170)$ \\
Year dummy & Yes & Yes & Yes & Yes \\
Industry*Year dummy & Yes & Yes & Yes & Yes \\
Firms & Yes & Yes & Yes & Yes \\
R-squared & 26 & 32 & 40 & 48 \\
\hline & 0.347 & 0.135 & 0.410 & 0.231 \\
\hline
\end{tabular}




\section{Table A4: Other Robustness tests}

This table includes the DID estimates of Russian domestic listed firms vis-à-vis Russian cross-listed firms after excluding post-reform cross-listed firms. In columns (1) and (2) we drop the firms with post-2003 foreign IPO. In columns (3) and (4) we also control London Stock Exchange (LSE) and New York Stock Exchange (NYSE) - two most popular stock exchanges for cross-listed Russian firms. In columns (5)-(6) we drop the firms with foreign controlling owners. Tobin's Q and EBIT/Assets are the dependent variables as proxies for operating performance and firm valuation. Robust standard errors in parentheses; $* * * \mathrm{p}<0.01, * * \mathrm{p}<0.05, * \mathrm{p}<0.1$.

\begin{tabular}{|c|c|c|c|c|c|c|}
\hline \multirow[b]{3}{*}{ VARIABLES } & (1) & $(2)$ & (3) & (4) & $(5)$ & (6) \\
\hline & \multicolumn{2}{|c|}{$\begin{array}{l}\text { Without post-2003 foreign } \\
\text { IPO }\end{array}$} & \multicolumn{2}{|c|}{$\begin{array}{l}\text { With control for Foreign } \\
\text { markets }\end{array}$} & \multicolumn{2}{|c|}{$\begin{array}{c}\text { Without foreign controlling } \\
\text { owners }\end{array}$} \\
\hline & Tobin's Q & EBIT share & Tobin's Q & EBIT share & Tobin's Q & EBIT share \\
\hline TD-Dummy-IV & $\begin{array}{l}-2.625 \\
(2.753)\end{array}$ & $\begin{array}{c}0.0709 \\
(0.0855)\end{array}$ & $\begin{array}{l}-3.062 \\
(2.580)\end{array}$ & $\begin{array}{c}0.0252 \\
(0.0788)\end{array}$ & $\begin{array}{l}-0.686 \\
(0.439)\end{array}$ & $\begin{array}{c}0.00542 * * * \\
(0.00194)\end{array}$ \\
\hline Domestic & $\begin{array}{l}-2.735 \\
(2.804)\end{array}$ & $\begin{array}{l}0.0610 * * \\
(0.0308)\end{array}$ & $\begin{array}{c}-3.884 * * \\
(1.943)\end{array}$ & $\begin{array}{c}-0.108 * * * \\
(0.0289)\end{array}$ & $\begin{array}{c}0.820 \\
(0.938)\end{array}$ & $\begin{array}{l}-0.00470 \\
(0.0181)\end{array}$ \\
\hline Domestic $\times$ TD-Dummy-IV & $\begin{array}{l}4.207 \\
(3.762)\end{array}$ & $\begin{array}{l}-0.0721^{*} \\
(0.0434)\end{array}$ & $\begin{array}{c}3.806 \\
(3.096)\end{array}$ & $\begin{array}{l}-0.0622^{*} \\
(0.0351)\end{array}$ & $\begin{array}{l}0.850 * * \\
(0.427)\end{array}$ & $\begin{array}{c}-0.00590 * * * \\
(0.00195)\end{array}$ \\
\hline Foreign mkt. LSE & & & $\begin{array}{c}-2.465 * * * \\
(0.561)\end{array}$ & $\begin{array}{c}-0.209 * * * \\
(0.0311)\end{array}$ & & \\
\hline Foreign mkt. NYSE & & & $\begin{array}{c}0.157 \\
(2.548)\end{array}$ & $\begin{array}{c}-0.158 * * * \\
(0.0203)\end{array}$ & & \\
\hline Constant & $\begin{array}{c}12.47 * * \\
(4.966)\end{array}$ & $\begin{array}{c}0.0322 \\
(0.0834)\end{array}$ & $\begin{array}{c}13.04 * * * \\
(3.828)\end{array}$ & $\begin{array}{l}0.147 * \\
(0.0802)\end{array}$ & $\begin{array}{c}10.90 * * * \\
(2.836)\end{array}$ & $\begin{array}{c}0.0719 \\
(0.0698)\end{array}$ \\
\hline Other control variables & Yes & Yes & Yes & Yes & Yes & Yes \\
\hline Industry dummy & Yes & Yes & Yes & Yes & Yes & Yes \\
\hline Year dummy & Yes & Yes & Yes & Yes & Yes & Yes \\
\hline Industry*Year dummy & Yes & Yes & Yes & Yes & Yes & Yes \\
\hline Firms & 43 & 46 & 43 & 46 & 47 & 50 \\
\hline R-squared & 0.228 & 0.069 & 0.265 & 0.146 & 0.527 & 0.139 \\
\hline
\end{tabular}




\section{Appendix 1: Construction of T\&D indices 2003-2007 by S\&P}

The survey is conducted by the Standard \& Poor's (S\&P in short). It uses only publicly available information, thus emphasizing that, a company's transparency score should not be compared with its corporate governance score (CGS), or otherwise interpreted as a measure of governance standards. A CGS is our assessment of a company's corporate governance practices, which is not limited to information disclosure. In addition, these scores are assigned on the basis of an in-depth, interactive analytical process involving both public and non-public data.

\section{Number of companies included}

The latest 2007 study covers 80 largest public Russian companies with the most liquid stock. In 2006, S\&P analyzed 70 companies. In 2005, 2004 and 2003 years the survey covered 54, 50 and 45 respectively.

\section{Criteria to select companies}

S\&P used two criteria to select the companies in the study: size and liquidity. As a rule, the liquidity of stocks positively depends on the size of the company, but there are exceptions, especially in cases of minor freefloat. There are more than 300 public companies in Russia, and this sample may not be representative of all Russian public companies. As the larger companies tend to be more transparent than smaller ones, our sampling method is likely to cause an upward bias in assessing transparency of the entire population of public Russian companies. On the other hand, as the companies included in the survey account for about $80 \%$ of the cumulative capitalization of the Russian stock market, they represent the major part of the Russian economy in terms of assets and operations.

\section{S\&P's industries covered}

S\&P covers such industries as Telecommunications, metallurgy, utilities, oil-and-gas, banking, food, consumer and retails and IT engineering. In our analysis we classify these industries between energy and non-energy sectors and compare those with all-industries together. We apply Classification Standard (GICS) codes to classify firms in our sample. As we focus on energy industry, GICS allowed us to identify 9 main energy subsectors within the energy industry. We have selected utilities and oil-and-gas producers as the two largest ones consisting $64 \%$ of overall energy sector. We provide the fill firms sample in the Appendix 2.

\section{Components of T\&D indices and scoring}

$\mathrm{S} \& \mathrm{P}$ have introduced six components and grouped these in three T\&D scores. Subject to these clarifications, these are:

- $\quad$ T\&D ownership structure and shareholders rights

- T\&D financial and operational information

- T\&D board and management structure

The first T\&D consists of "ownership structure" and "shareholder rights" which represented by 17 questions each. The next T\&D is a composition of "financial information" and "operational information" disclosure. These are based on 31 and 16 questions respectively. The last third T\&D scoring consists of "board and management information" and "board and management remuneration", based on 16 and 8 questions. S\&P then calculated the scores for each answer in every section and provided with the total scores for each T\&D for the observed companies. The score has a range of minimum $0 \%$ and maxim $100 \%$ for the best transparency \& disclosure. S\&P does not explain the methodology behind the percentage score as it uses specially designed method. We show the T\&D scorings for each observed company in Appendix 2.

\section{Component 1. Ownership structure}

\section{Disclosure of:}

1. The number and par value of issued ordinary shares.

2. The number and par value of issued other types of shares disclosed.

3. The number and par value of authorized but unissued shares of all types.

4. The identity of the largest shareholder.

5. The identity of holders of all large stakes (blocking: $>25 \%$; controlling: $>50 \%$ ).

6 . The identity of shareholders holding at least $25 \%$ of voting shares in total.

7. The identity of shareholders holding at least $50 \%$ of voting shares in total.

8. The identity of shareholders holding at least $75 \%$ of voting shares in total.

9. The number and identity of each shareholder holding more than $10 \%$.

10. The indication that management is not aware of the existence of any stake exceeding $5 \%$ in except for those that are reported.

11. Shareholding in the company by individual senior managers.

12. Shareholding in the company by individual directors.

13. The description of share classes.

14. A review of shareholders by type.

15. The percentage of cross-ownership. 
16. Information about listings on exchanges.

17. Information about indirect ownership (e.g., convertible instruments).

\section{Component 2. Shareholder rights}

\section{Disclosure of:}

18. Corporate governance charter or corporate governance guidelines.

19. Evidence of existence of a code of business conduct and ethics.

20. The contents of the code of business conduct and ethics.

21. Articles of association (including changes).

22. Voting rights for each voting or nonvoting share.

23. The way that shareholders nominate directors to the board.

24. The way that shareholders convene an extraordinary general meeting (EGM).

25. Procedure for initiating inquiries with the board.

26. Procedure for putting forward proposals at shareholders meetings.

27. Formalized dividend policy.

28. Announcement of recommended dividends before the record date.

29. Review of the last shareholders meeting.

30. Full general shareholder meeting (GSM) minutes.

31. Calendar of important shareholder future dates.

32. GSM materials published on the Web site.

33. Detailed press releases covering last corporate events.

34. Policy on information disclosure.

\section{Component 3. Financial information}

\section{Disclosure of:}

35. The company's accounting policy.

36. The accounting standards it uses for its accounts.

37. Accounts according to local standards.

38. Annual financial statements according to an internationally recognized accounting standard (IFRS/U.S. GAAP).

39. Notes to annual financial statements according to IFRS/U.S. GAAP.

40. Independent auditor's report on annual financial statements according to IFRS/U.S. GAAP.

41. Unqualified (clean) audit opinion on annual financial statements according to IFRS/U.S. GAAP.

42. Audited IFRS/U.S. GAAP financial statements published before the end of April.

43. Unaudited IFRS/U.S. GAAP financial statements published before the end of April.

44. Audited IFRS/U.S. GAAP financial statements published before annual general meeting.

45. Unaudited IFRS/U.S. GAAP financial statements published before the end of June.

46. Disclosure of related-party transactions (RPTs): sales to/purchases from payables to/receivables from related parties.

47. Indication that RPTs are made on market or nonmarket terms.

48. Exact terms of RPTs.

49. Interim (quarterly or semi-annual) financial statements according to an internationally recognized accounting standard (IFRS/U.S. GAAP).

50. Notes to these financial statements.

51. Whether these financial statements are audited or at least reviewed.

52. Consolidated financial statements according to the local standards.

53. Methods of asset valuation.

54. A list of affiliates in which the company holds a minority stake.

55. The ownership structure of affiliates.

56. A basic earnings forecast of any kind.

57. A detailed earnings forecast.

58. Segment analysis (results broken down by business line).

59. Revenue structure (detailed breakdown).

60. Cost structure (high degree of detail).

61. The name of the auditing firm.

62. Whether the audit firm is a top-tier auditor.

63 . Auditor rotation policy.

64 . How much the company pays in audit fees to the auditor.

65. Whether auditor renders non-audit services.

66. Non-audit fees paid to the auditor. 


\section{Component 4. Operational information}

\section{Disclosure of:}

67. Details of the type of business the company is in.

68. Details of the products or services the company produces or provides.

69. Output in physical terms.

70. A description of functional relationships between key operating units within the group.

71. Industry indicators that allow comparison with peers.

72. Other financial indicators.

73. Characteristics of fixed assets employed (including licenses).

74. Efficiency indicators.

75. A discussion of corporate strategy.

76. Any plans for investment in the coming years.

77. Detailed information about investment plans in the coming year.

78. An output forecast of any kind.

79. An overview of trends in its industry; regulatory environment with regards to industry.

80. The market share for any or all of the company's businesses.

81. Social reporting (e.g., Global Reporting Initiative).

82. Overview of compliance with environmental law.

83. Principles of corporate citizenship.

\section{Component 5. Board and management information}

\section{Disclosure of:}

84. The list of board members (names).

85. Details about the current employment and position of directors.

86. Other details: previous employment and positions, education, etc.

87. When each director joined the board.

88. The name of the chairman.

89. Details about role of the board of directors at the company.

90. A list of matters reserved for the board.

91. A list of board committees.

92. Names of all members of each existing committee.

93. The bylaws on other internal audit functions besides the audit committee.

94. Information about the ratio of in absentia and in person board meetings.

95. Attendance record for board meetings.

96. The list of senior managers not on the board of directors.

97. The backgrounds of senior managers.

98. The non-financial details of the CEO's contract.

99. The number of shares held in other affiliated companies by managers.

100. Policy on assessment of board of directors and on training provided to them.

\section{Component 6. Board and management remuneration}

\section{Disclosure of:}

101. The decision-making process for directors' pay.

102. The specifics of directors' pay, including the salary levels.

103. The form of directors' salaries, such as whether they are in cash or shares.

104. The specifics of performance-related pay for directors.

105. The decision-making process for determining managerial (not board) pay.

106. The specifics of managers' (not board) pay, such as salary levels and bonuses.

107. The form of managers' (not board) pay.

108. The specifics of performance-related pay for managers. 


\section{Glossary of terms}

VARIABLES

Variable definitions

Tobin's Q (tq2)

EBIT_TA

Td_overall

TD_Dummy

TD_Dummy-IV

Reform

Domestic

Firm age

Log(total assets)

sizeq4

sizeq3

sizeq2

Tangibility

Tax rate

Return on equity

Market to book ratio

Insider holding

Controlling owner

Statecontrol

Foreign controlling

shareholder

EQ1

EQ2

EQ3

EQ4
Market capital plus debt as a share of total assets

Share of EBIT to total assets

Composite transparency and disclosure index (continuous variable)

A binary variable that takes a value 1 if the T\&D score is $>0$ and 0 otherwise during 2003-2007

Predicted value of TD_Dummy using estimates shown in Table A1

A binary variable that takes a value 1 for 2004-07 and 0 otherwise

A binary variable that takes a value 1 for Russian listed firms which are not crosslisted in a foreign exchange market

Firm's age in years

Log of total assets

Size dummy based on total assets: top quartile 4

Size dummy based on total assets: quartile 3

Size dummy based on total assets: quartile 2

Share of intangible assets to total fixed assets

Total tax payments as a share of EBIT

Net income as a share of book value of equity

Market capital as a share of book value of equity

1 if the controlling shareholder is a manager of the company

A dummy variable taking a value 1 if a domestic ultimate owner (state or private)

holds $>=50 \%$ share of ownership and 0 otherwise

A dummy variable taking a value 1 if the domestic ultimate owner is a public authority holding $>=50 \%$ share of ownership and 0 otherwise

1 if the controlling shareholder of the domestic firm is foreign individual/institution and 0 otherwise

Measure of earnings quality: ebit as a share of cashflow

Measure of earnings quality: sd of EBIT/sd of cashflow

Measure of earnings quality: sd of ebit/mean of ebit Measure of earnings quality:operating accrual/total assets 